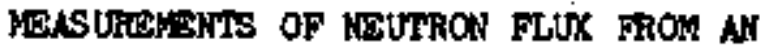

\section{INTERIAL-ELPCTROSTATIC COHFTVMIITT}

DEVICS

Technlcel Feport

\author{
Glen A. Nestenskow \\ Brighan Young University \\ Frovo, Utah.
}

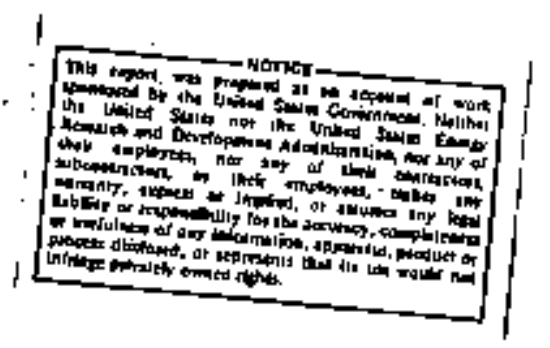

August, 1975

\section{MASTER}

PFEPARED FOR THE U,S. ATONIC GIJEAY CONMTSSION

UNDER CONTRACT HO, AT(11-1)-2180 


\section{DISCLAIMER}

This report was prepared as an account of work sponsored by an agency of the United States Government. Neither the United States Government nor any agency Thereot, nor any of their employees, makes any warranty, express or implied, or assumes any legal liability or responsibility for the accuracy, completeness, or usefulness of any information, apparatus, product, or process disclosed, or represents that its use would not infringe privately owned rights. Reference herein to any specific commercial product, process, or service by trade name, trademark, manufacturer, or otherwise does not necessarily constitute or imply its endorsement, recommendation, or favoring by the United States Government or any agency thereof. The views and opinions of authors expressed herein do not necessarlly state or reflect those of the United States Government or any agency thereof. 


\section{DISCLAIMER}

Portions of this document may be illegible in electronic image products. Images are produced from the best available original document. 




\title{
TNERTIAL-ELECTRCSTATTC CONFTHENONT
}

DEVICD

\author{
Glen A, Hestenskow \\ Departinent of Fhyslcs and Astremnamp \\ M.S. Degree, Ap-i1 $19 \%$
}

ABSTAACT

A neutron-detection systex has been built for the purpose of measuring the neutron flux from an Inertial-Electrostatic Confinement Device located at Brighan Young University. A EF, proportional

counter was used for absolute flux measurements ald a pals of scintillation detectors was useri to compare neutron output under different operating conditions. The detectors were designed to be compatible wh the operating conditions of the device and to be able to measure small changes in neution output. The detectors were callbrated using a Pu-Be source with corrections made for laboratory conditions. Performance of the counting system was checked and data were collected on the neutron flux from the device.

COMHITRES APFROVAL:
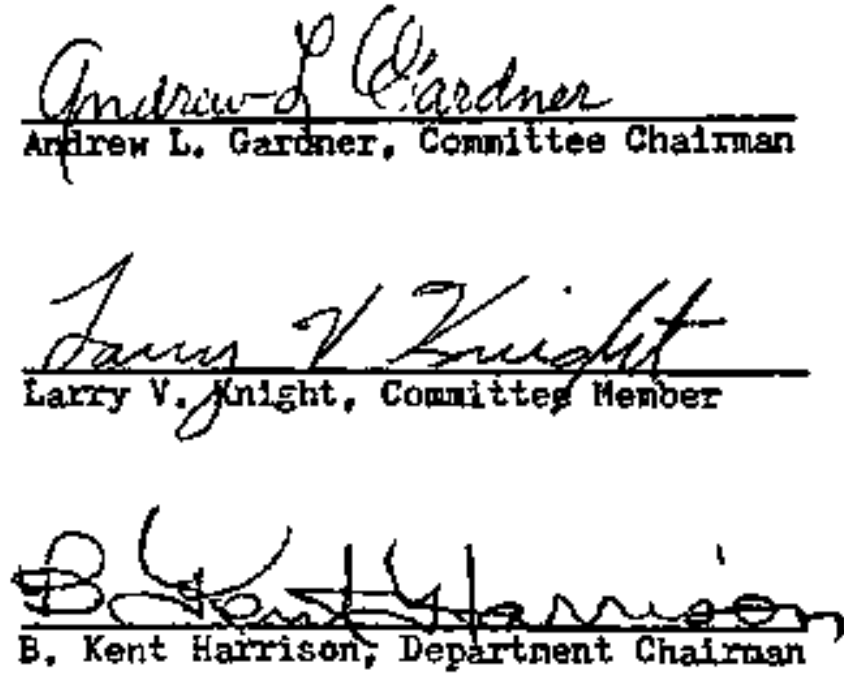
Th1s thesit, by Glen A, Westenskow 15 accepted in 1tg present form by the Department of Physics and Astronony of Brighan Young Univeraity as satisfying the thesis requirenent for the aegres of Master of Sclence.

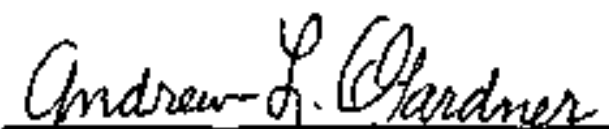

Anfres L. Garther, Connittes Chatiman
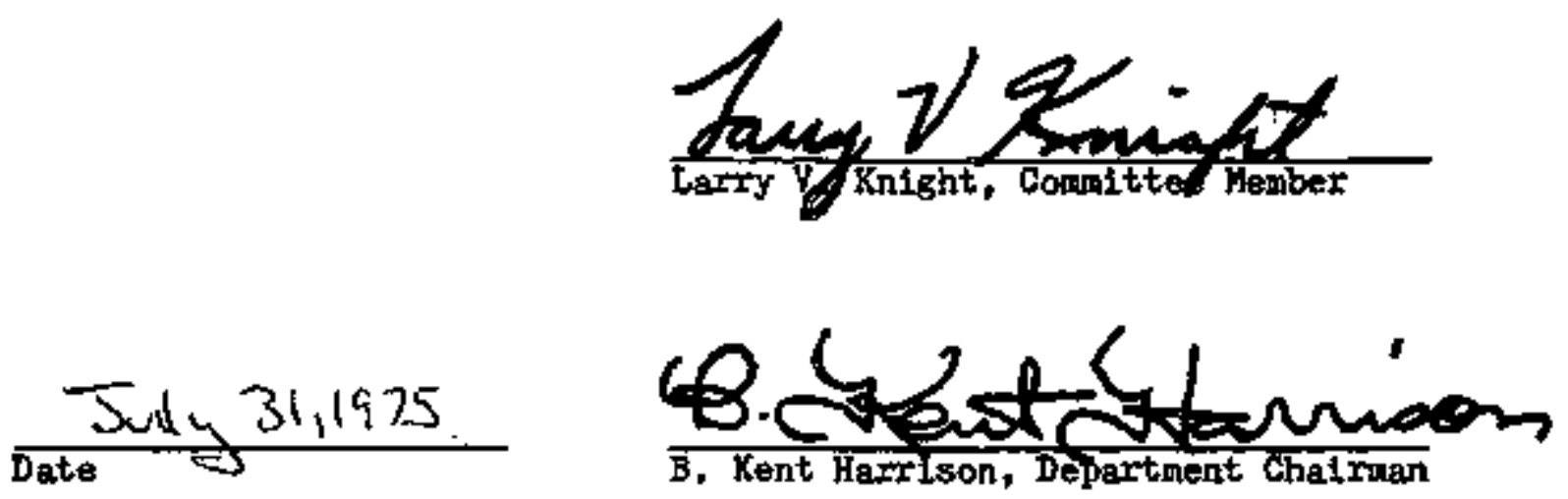


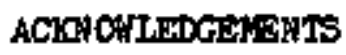

The author wlahes to express gratitude to his major professor, Dr. Andrew L. Gardner, for his help, advice, and encouragenent during the project. The author owes great appreclation also to Dr. Iarry Knight for this help and confldence during the past two years. Acknowledgenents are also made to co-worker, Austen Chan, for his diligent work on the experinent. Special theniss go to the author's family for their concern and support over the years.

The author slso wishes to give thanks to those professors who have nade special efforts in their teaching or in givine ald during the author's study here.

The U. S, Atonde Energy Conmission under contract No. At(11-1)-2180 has helped to support this project. Minanctal assistance was also provided through a BYL regenteh internship. 
TABIE OF CONTENTS

Page

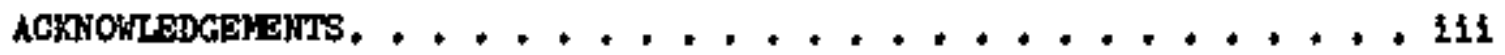

LIST OF FIGURES $, \ldots, \ldots, \ldots, \ldots, \ldots, \ldots$

Chapter

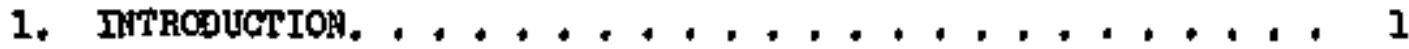

The Confinement Devlce. ................. 1

2. DEHECTYON AND SPECTROSCOPY OF FAST MEUTROLS BY

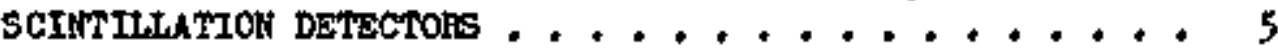

Gamma-Hay D1serimination. .............., ?

Background-Rate Considerations, . . . . . . . . 8

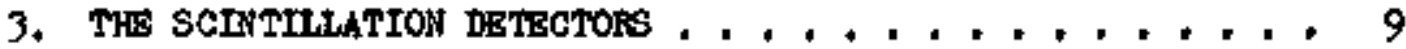

Lead Shielding for the Detector ..........., 12

4. CaLIBRation of THE Datectors. ............... I9

The Plutoniun-Berylliun Source. ........., . 19

Boron Trifluoride Proportlonal Counters ........ 20

Gallbration of $\mathrm{BF}_{3}$ Detector . . . . . . . . 21

Calibration of Sclntillation Detectors. . . . . . . 24

Efficlency of the Scintillation Detector. . . . ... 27

Energy Collbration. . ................. 27

5. SNITCHҢD OPERATIOH, ................... 33

6. sumuar .......................... 38

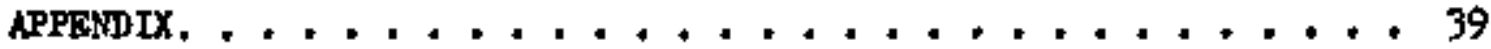

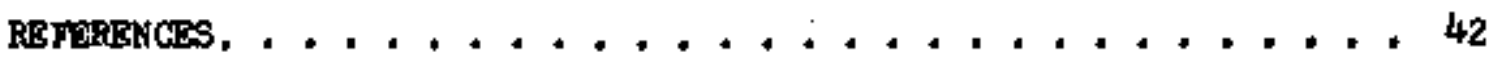


1. The Confinenent Derice. .................. 2

2. Dlagrax of the Confinement Device............. 3

3. Pulse-Height Spectrun for a Monoenergetic Neutron Beal in the Ideal Case. .............. 6

4. Pulse-flejght Spectrun for a Monoenergetic Neutron Bean in the Regl Case.............. 6

5. Digram of the Scintillation Detector ......... 10

6. Neutron Counter. .................... 11

7. Voltage-Divider Network for the Fhotonultiplier Tubes . . 13

8. Arrangement for Puise-Helght Analys1s........... 14

9. Arrangenent for Measuring Counting Hates. ........ 15

10. Transattance of Gamla Rays through One Inch of Lead. * . 16

11. Gamna-Ray Hadiation in the Fegion of 50 keV or Higher . . 17

12. The Value of $\mathrm{C}$ as a Function of Distance......... 23

13. Comparison of Counting Rates for the $\mathrm{BF}_{3}$ and the Scintillation Detector for the Steady Case. ...... 25

14. Measurenents of Neutron Fux frovt the Confinenent Device. - 26

15. Known Energy Spectrum of a Pu-Be Source . . . . . . 29

16. Bnersy Spectrun of the Protons Scattered by the Neutrons for the Pu-Be Source Used ............... 30

17. Derivat1ve of the Energy Spectrun Shown In FIg, 16. . . 31

18. Frergy Spectiun of the Protons Scattered by the Neutrons from the Confinesent Device............. 32

19. Cathode Voltage and Gating Pulse During a Swltching cycle . 34 
20. Countins Hates During a SwItchlng Cycle for $\mathrm{D}_{2}$ and for

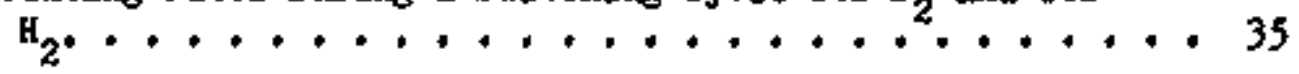

21. Comparison of Counting Rates of $\mathrm{BP}$ and the Seintillation

Detectors for the Sultched Condition. ....... 36 
Chapter 1

DITRODUCTIO

The we of xadiation detectors has played an essential role In the developinent of reactor phytes. In analyaing the operation of an Inerilal-Blectrostatic Confinenent Device a neasurenent of the neutron flux from fusing deuteriun lons is a valuable diagnostic tool. This thesis describes studies of this nature that were performed on such a device at Brtghan Young University. In order to evaluate sabli changes in operating conditions of the device, a detector with high sonsitivity was needed. Two scintillation detectors were constructed for this purpose. They were deslgned to be able to nake measurenents sinultaneously with electron density neasurenents and to be able to make comparlson of different operating conditions. The detectors were callbrated in ordez to make both absolute and relative neusurenents of flux from the device.

\section{The Conflnement Derlee}

The concept of Inextial-Blectrostatic Confinenent was concelved nearly twenty years ago. Since that tine several confinenent devices of this type have been bullt and tested to deternine their ab111ty to conflne and concentrate lons.

The confinenent device (Mg. 1 and 2) studied at Brigham Young University basically consiets of two concentric spherical shells and s1x Ion guns. The outex sphere serves as an anode at ground potential 


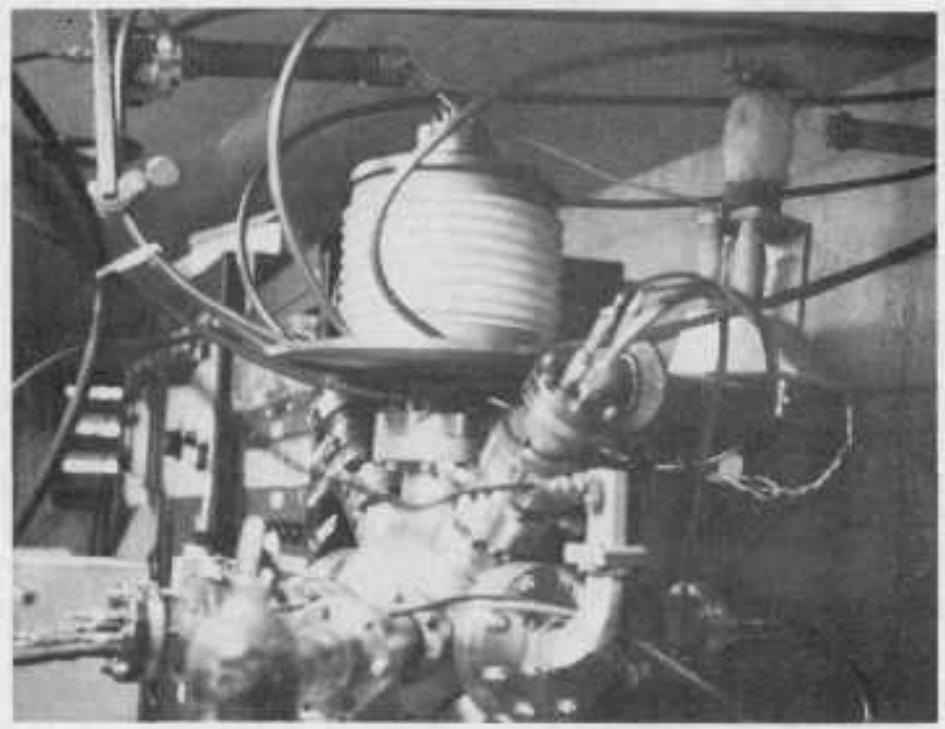

The Confinement Device (below the insulator) showing also the Voltage-viewing Resistor, the Voltage Vacuun Switch, and the Microwave Output.

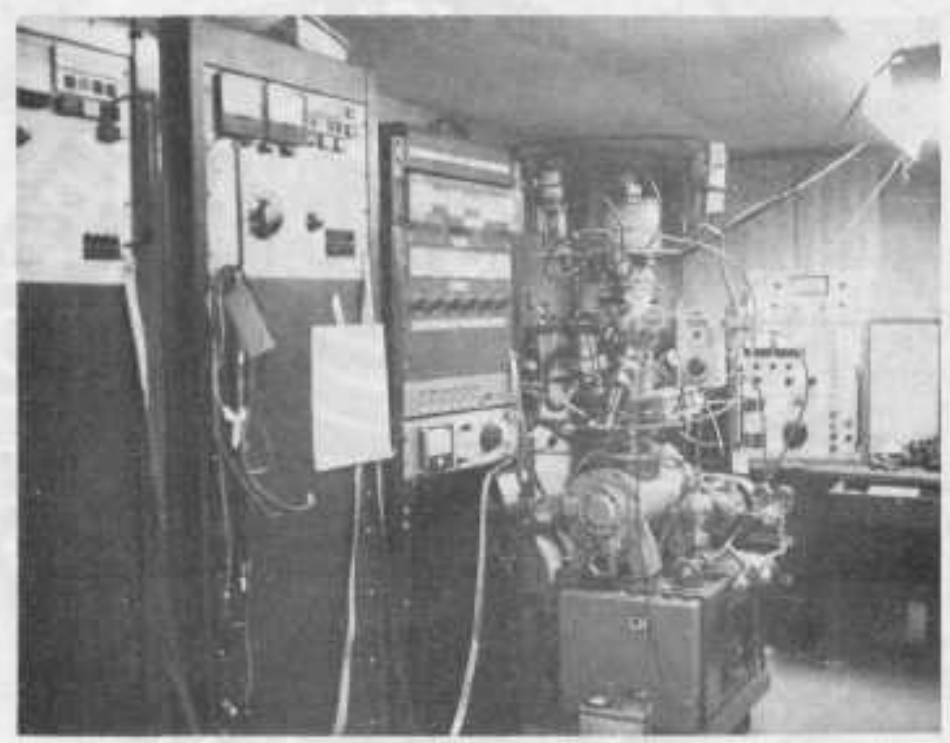

Another V1ew of the Confinement Device with its High Voltage Power Supply. Four of the six lon guns are clearly visible.

Figure 1. The Confinement Device 


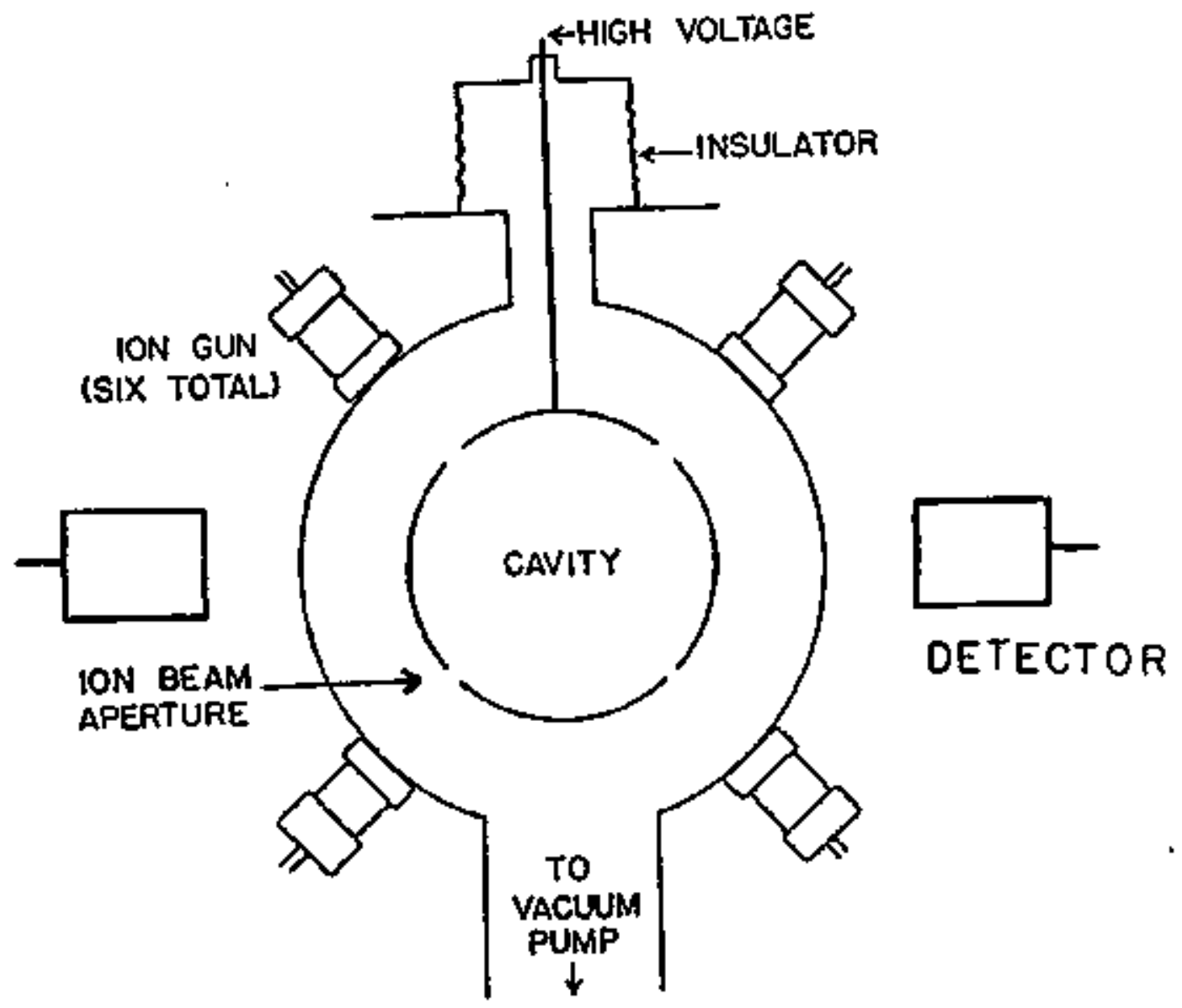

Flgure 2. Diagran of the Confinenent Device 
on which the lon guns are mounted. The inmer sphere is a high potential cathode. Hobert I. Hirsch ${ }^{l}$ has discussed the theory and operation of a confinement device sinilar to the one tested at BYl.

Two selntillation detectors were used so that all guns would be equally favored by the detectlog systen. They were placed so that as large a solid angle as was practical was covered. The results of the relative measurements were used by Austen chan ${ }^{2}$ for an evaluation of the device. This thesis does not include an evaluation of the conflnenent device 1tself. 
Chapter 2

DETECTION AND SFPCTHOSCOPY OF FAST NEUTROAS

BY SCTNTILATION DETGGIOES

The use of scintillator counters has become popular for the detection of fast neutrons. The density of the naterial allows for higher detection efficiencles than that phich characterizes geses. The fast response of the natertal to neutrons pexalts high counting Iates and the light output is related to the energy of the inconing neutrons. The shape of the naterial can be chosen to allow counting over large solid angles and the materlal has good light-transnision properties.

Since neutrons lack charge, they are not detected directly through electromagnetic Interactions but from scattering events with protons. The selntillator natarlal contalns a large number of hyirogen nuclei to which the high energy neutrons give up energy in scattering events. The energetic hyirogen nuelei then react eleotronagnetically, biving off a pulse of light from each iateracting neutron. For energies beloy 10 WeV the $n-p$ scattering prosess is 1sotropic in the center-of-nass syaten. ${ }^{3}$ In such a case it can be shown that for a monoenergetic neutron beam the pulse-height spectrun (Fig. 3) ideally would conslst of a flat distribution of pulsen from zero energy up to the energy of the inconing bean. However, there are several factors which alter the spectrun to look nore 11ke Flg. 4. One of 


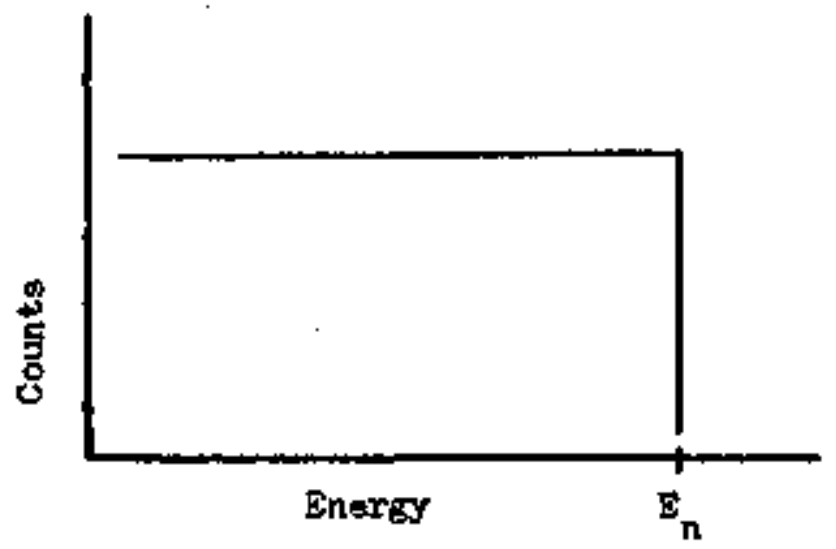

Flgure 3. Pulse-Helght Spectrum for a Monoenergetic. Bear in the Ideal case

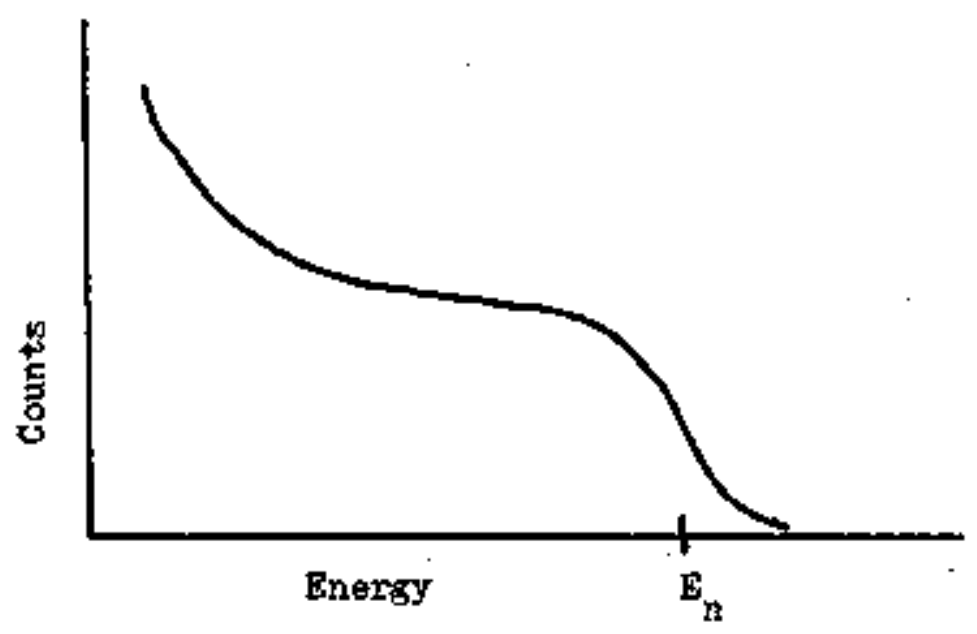

Flgure 4. Pulse-Height Spsetrun for A Monoenergetic Bean in the Hear Gase 
the injortant factors is the nonlinear response of the seintillator to protons, Also many of the neutrons ste moderated due to collistons with material before they reach the detector, Another consideration is the presence of carbon nuclei which also scatter the bean but with a different response. The linited size of the scintillator and the resolution of the counting systen also alter the resulting spectzun. These factors limit the appication of this type of detector for work in spectroscopy, however it does have a high detection efficiency for fast neutrons.

\section{Gania-iay Discrtination}

Infortunately for neutron detection the scintillator materlal is sensitive to ganns rays as weIl as to neutrons. Lead shielding areund the detector w11l have a mueh larger effect on stopping gamna rays from reaching the sensitive solntillator than it does on the reutrons. This is especially effective against low-energy gama rays entering the detector. A quantitative example will be given later under a discussion of the detector.

Often, however, a means of discrimination 1s needed to avotd unwanted counts of ganma rays. In plastic scintillators the pulse resulting from a neutron ezent has a shape different fron that of a gama-ray event, the pulse belng flatter for the nettron. ${ }^{4}$ This effect can be used to discriminate betwen the two events by electron1e means. As till be discussed later, tests were performed wh1ch indicated that thls more sophisticated method was not necessary for the present experinent. 
Backeround-Rate Considerations

Fven without a deliberate source there will be light pulses In the scintillator material due to casnic rays and radtoactive naterial in the environment. This background pulse rate is affected by the laboxatory conditions so it needa to be neasured under conditions that are similar to those of the experiment. A high beckground rate in comparison to the sample rate will linit the senaltivity of the neasurenent, Shielding the detector and liniting 1ta size will reduce the number of counts from the sample. The slze and shape of the detector should be chosen to optinlze the slengl-to-noise ratio. 
Chapter 3

THE SCDNRLLTION DKRECTORS

Two ident1cal scintillation detectors (F1gs, 5 and 6) were bullt for sinultaneous use in the oxperinent. To nake the desired neasurewents the detector systen needed to have good sensftivity to neutroks with a few MeV of energy, and to be able to aeasure the flux of neutrons over the greatest solid angle that was practical.

The plastic selntillator naterlal used was a product of Nuclear Enterpalzes (NE 110). The block of materfal used for each detector was cylindrical in shape with a dlaneter of five inches and a length of five inches. The end that was coupled to the photomultiplier tube was polished and all other surfaces were given reflective coating of Titanlum Dioxide. Silfcone grease, whlch is often utilized to improve the light transurssion between the scintillator and photonultipller tube, was avoided in order to nake the contact more reproduc1ble. The scintillation material produces pulses with a width of 3.3 nsec, a Aecay time of 3.3 nsec, a maximun en1ssion wavelength of $434 \mathrm{~nm}$, and a light attenuation length of $400 \mathrm{~cm}^{5}$

The photomultiplier tubes used mere experimental models built by fach that were obtained through a governnent surplus outlet. They have a 14-stage venetian-blind construction with a f1ve-inch face, Test data on each tube, taken at the tine of fabrication, were obtalned through a hCA representative in Lancaster, Pennsylvan1a, The append1x 


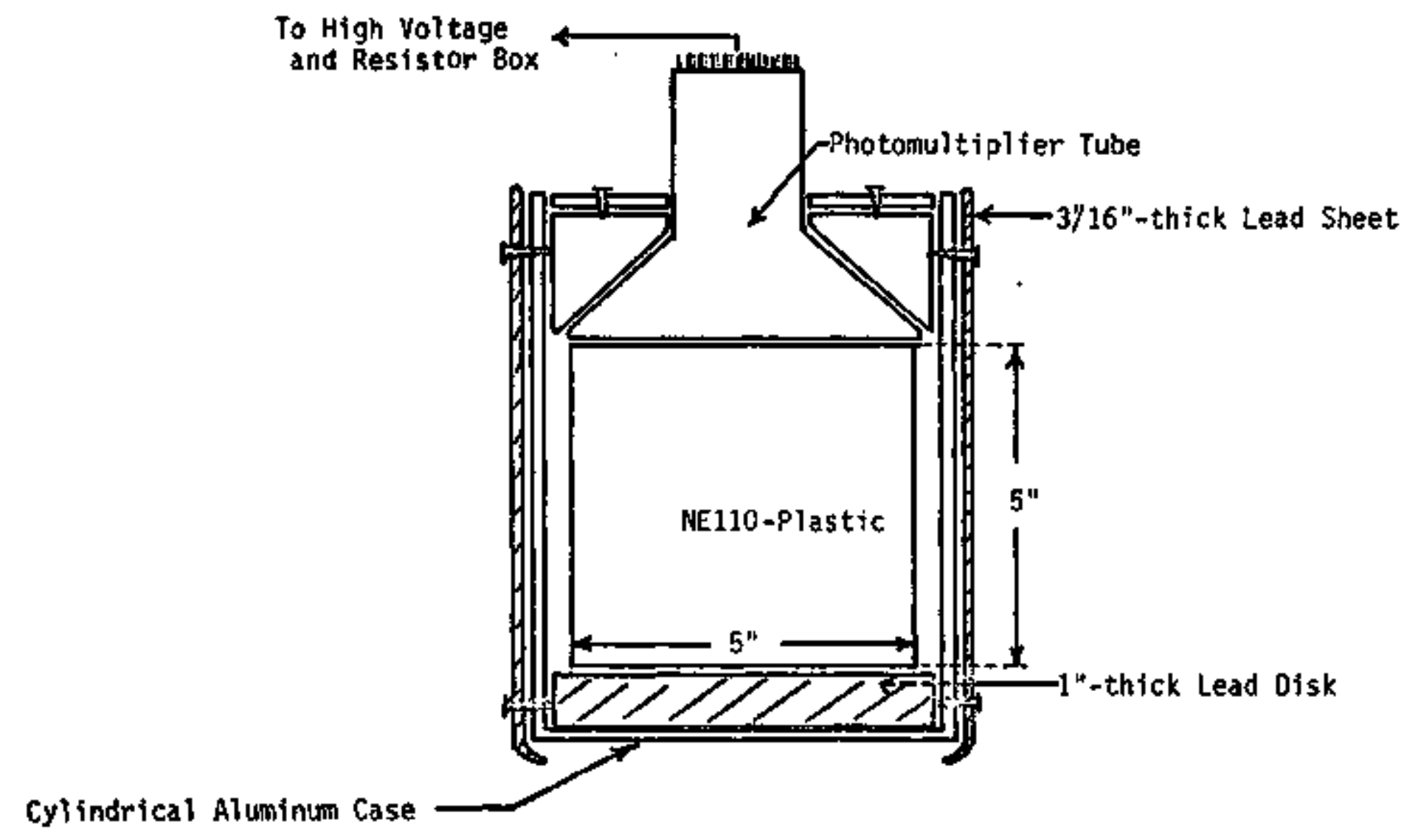

Figure 5. Dlagram of the Seintillation Detector 


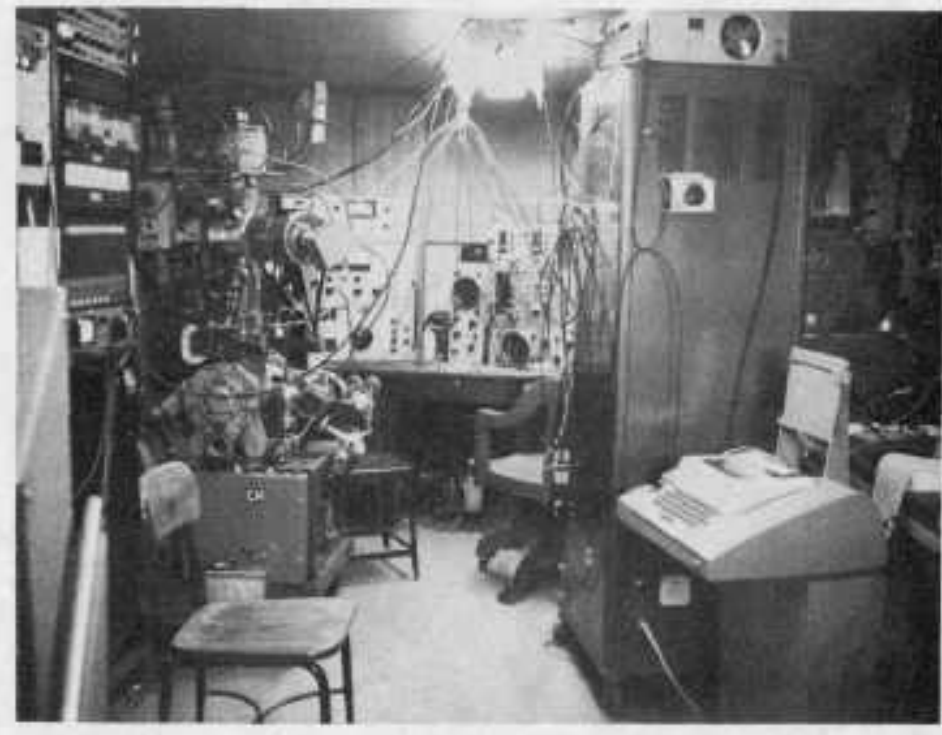

An Overall View Showing Counting Equipment (on the desk at the rear, and Teletype in right foreground).

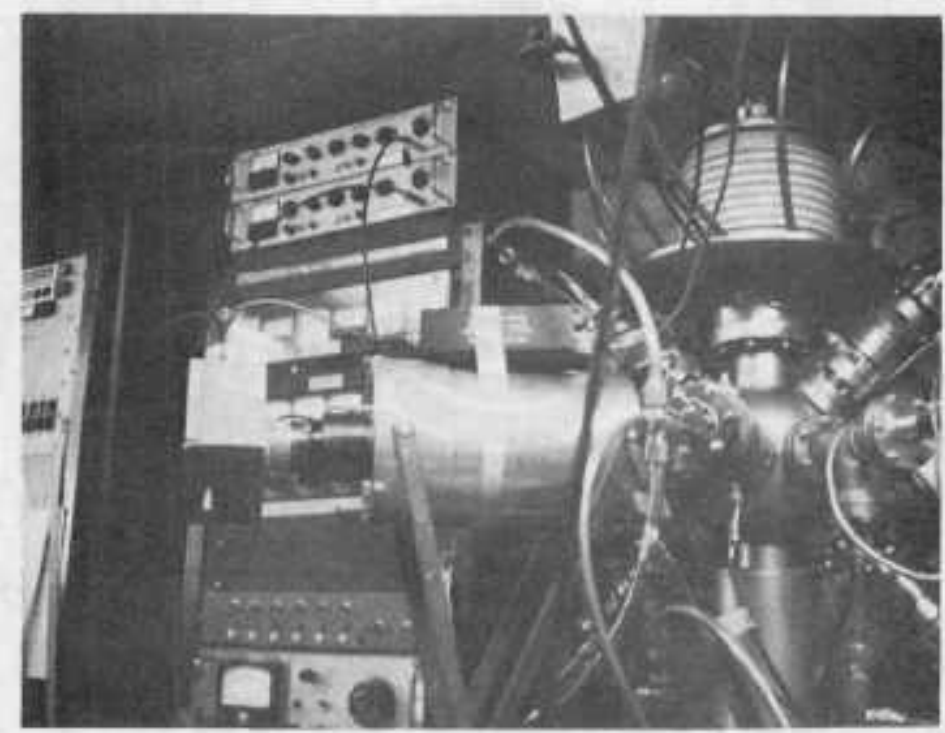

A View of One of the Scintillation Detectors

Figure 6. Neutron Counter 
contains inforation of the two tubes used $(x-36150, x-36246)$ and also on two additional tubes that were obtalned at the eane tine.

The tubes were powered through a voltage-divider network (F1g. 7) that was bullt for the experinent. The slogal output was A.C.coupled to the preamplifters for pulse-analys1s work, Fis. 8 shows the arrangement used for pulse-hetght analysis and Fto. 9 that used for measuring activity rates.

\section{Lead Shletaing for the Detector}

To reduce the number of gama rays belng counted, an inch of lead sblelding was placed in the front of the detector, Heutrons of one to four HeV are reduced by only about $9 \%$ by the lead while nast of the low energy gaming rays are absorbed. Fig. 10 show the transnittance of gama rays through one 1nch of lead as a function of energy. 6

As a verlflcation that the counts recorded were a result of fusion reactions, rather than coming fror other soures, hydrogen was substituted for the deuteriun which was normally used to supply the Ion guns, At voltages below $40 \mathrm{kV}$, the counting rate rematned at baskground level for hydrogen, while for the same settings the counting rate for deuteriun was appreciable. The counting rate increased for voltages above this level (FLg. 11), but all measurements taken slnultaneously with electron density negsurenents were perfozmed belou 40 keV because of the voltage stand-off lindtation of the high-roltage switch. Thus, for mins below $40 \mathrm{KeV}$, the coints recorded wh douteriun operation were considered to result fron furgion reactions. To extend the useful range of the detectors, an additional 3/16 1nch of 


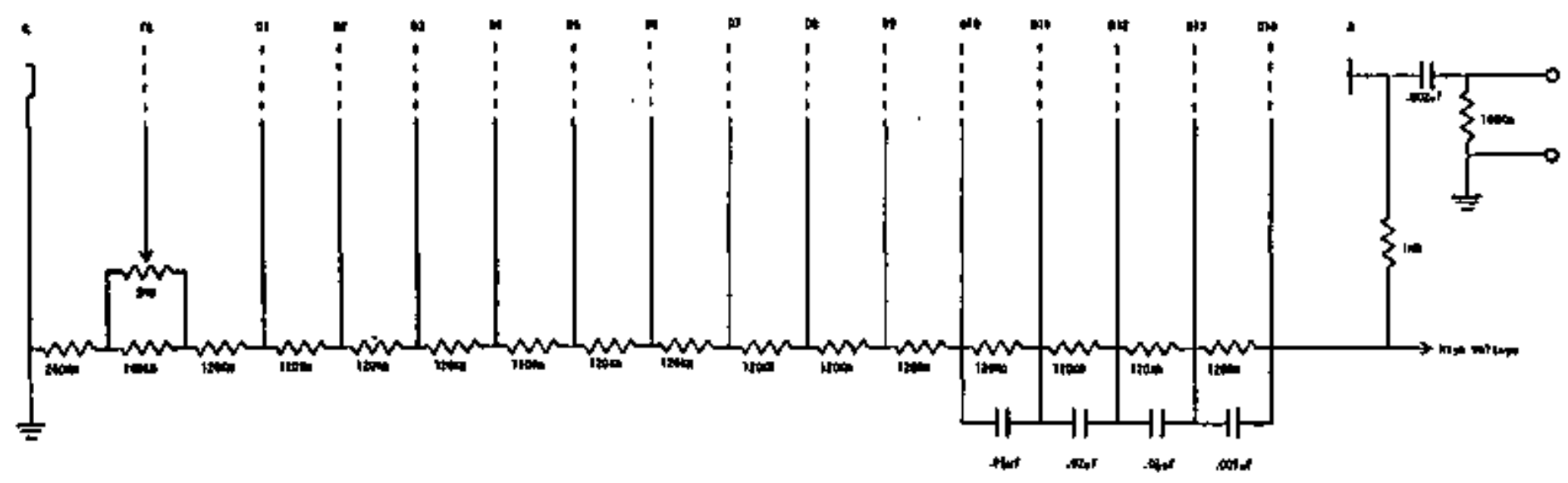

Figure 7. Voltagemdivider Netwoxk for the Photonultiplier Tubes 


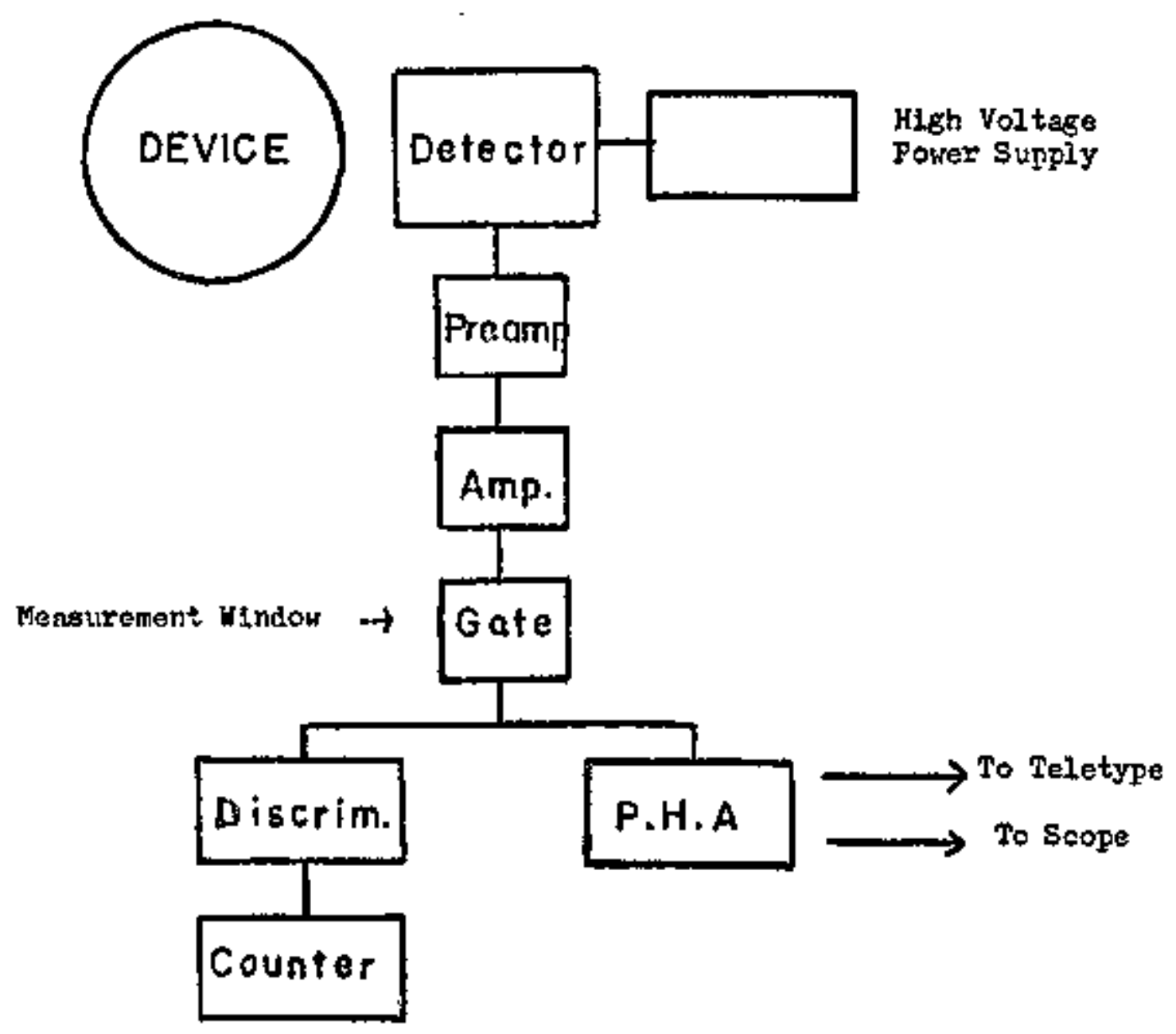

Flgure 8. Arrangement for Pulso-Helght Analyola 


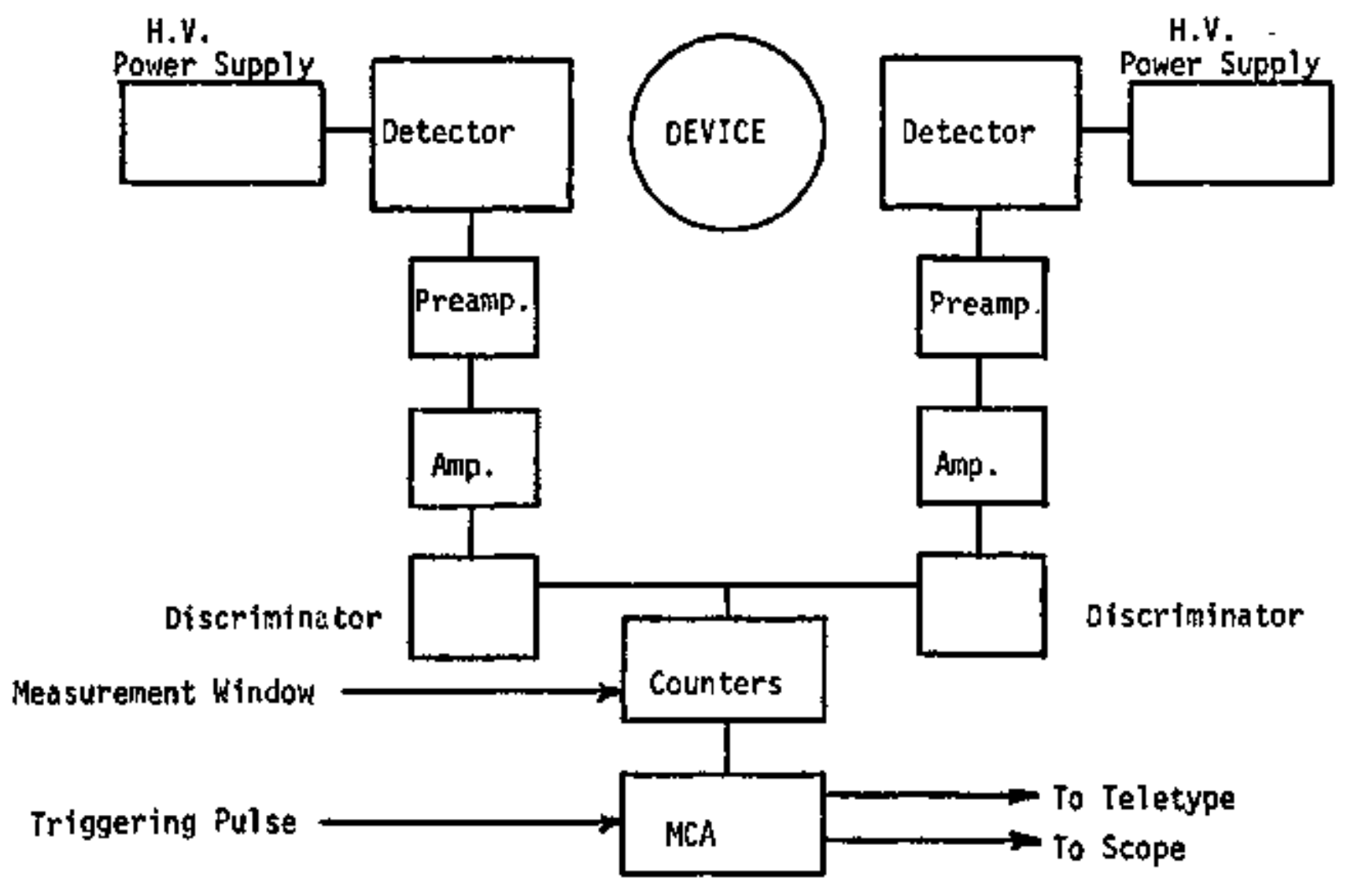

Figure 9. Arrangement for Measuring Counting Rates 


$$
\square
$$




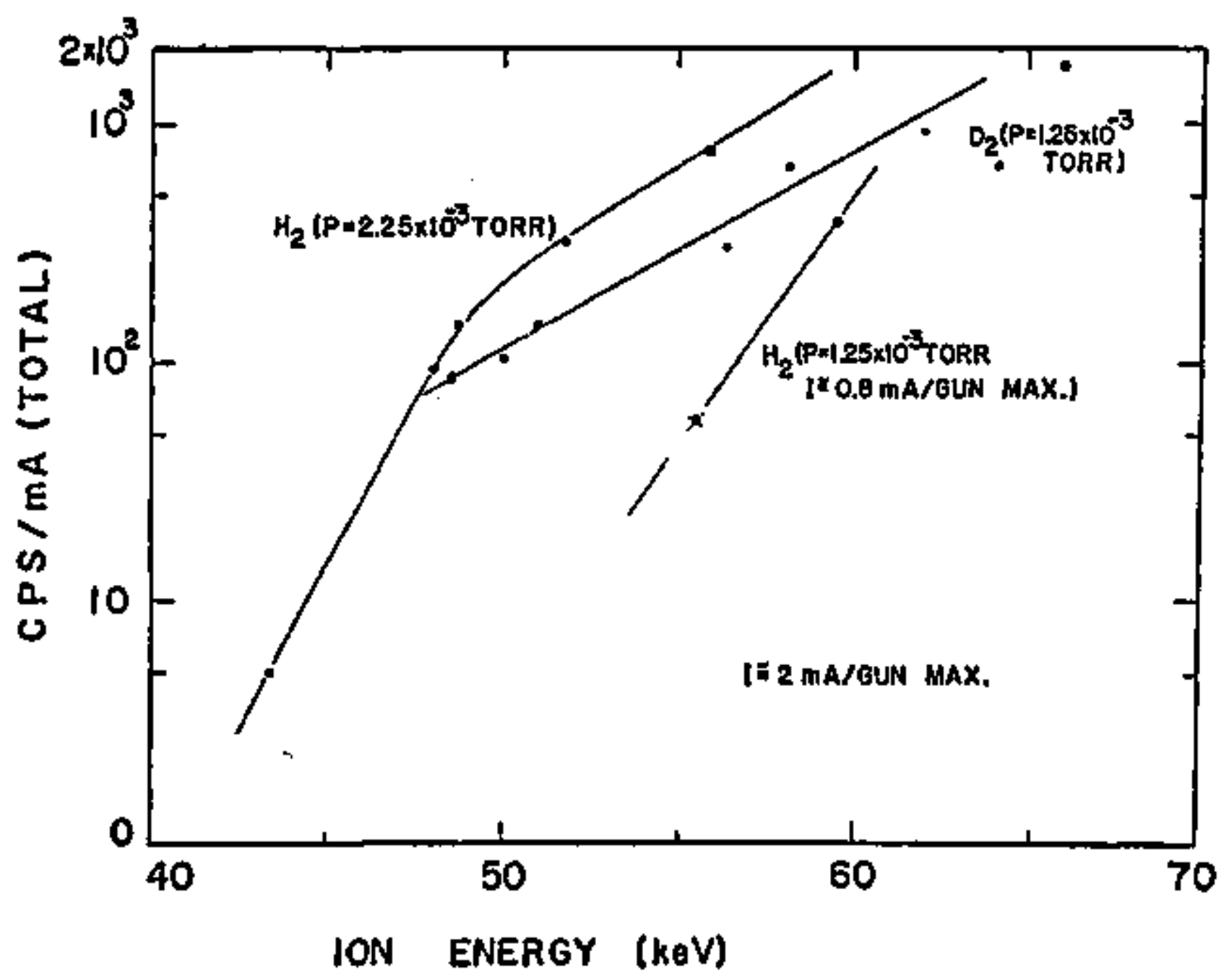

Flgure 11. Gama-Ray Radiation in the Region of 50 keV of Higher 
lead shielding was placed around the detectors. With this adaitional ahielding counting rates repalned near background for voltages below $50 \mathrm{keV}$. The maximun voltage obtainable with the removal of the high voltage switch tas $65 \mathrm{keV}$. At thlo level the counting rate for deuteriun renained substantially above that for hyirogen. This indicated that additional means of discrinination between neutron and gavona rays was not necessary under the operating conditions that were used. 
Chapter 4

\section{CALIBARTION OF THE DETECTORS}

To deternlne the absolute flux fron the confinenent devioe, a BF $_{3}$ proportional counter was used which was calibrated with a Pu-Be source. The $\mathrm{Br}_{3}$ counter was then used to callbrate the acintillation counters. The scintillation detectors were also ised to Indicate the approxinate energy suectruts of the neutrons from the device.

\section{The Plutonium-Bery?livm}

Souree

To detemine the sensitivity of the detectors, a Pu-Be source was used whose activity and conposition were neasured in 1962 by the nanufacturer. ${ }^{7}$ The composition at that time was $91.57 \% \mathrm{Pu}^{239}, 7.73 \%$ $\mathrm{Pu}^{240}$, and $.70 \% \mathrm{Pu}{ }^{241}, \mathrm{Pu}^{241}$ has a nean $\mathrm{Iife}$ of 18.6 years and decays to $\mathrm{Am}^{241}$. $\mathrm{Pu}^{239}, \mathrm{Pu}^{240}$, and $\mathrm{Am}^{241}$ have long half IIves and decay w1th the enission of alpha particies. The alpha particles then interact with the Berylliun to give off neutrons ( $\mathrm{Be}+\mathrm{He}^{4} \rightarrow \mathrm{C}+\mathrm{n}+$ energy). Since $\mathrm{Pu}^{241}$ was present in the source, its strength (1.e., the neutron enlssion rate) has changed over the last thirteen years. The following equation ${ }^{8}$ was used to estimate the present activity.

$$
Q_{t} / Q_{0}=1+k[1-\exp (-t / 18.6 y)]
$$


where in our case

$$
\begin{aligned}
& \mathrm{k}=1.27 \mathrm{a}\left(\mathrm{Pu}^{241}\right) / \mathrm{T}\left(\mathrm{An}^{241}\right) \\
& \mathrm{a}\left(\mathrm{Pu}^{239}\right)+\mathrm{a}\left(\mathrm{Pu}^{240}\right) \\
& \mathrm{T}\left(\mathrm{Pu}^{239}\right) \quad \mathrm{T}\left(\mathrm{Pu}^{240}\right)
\end{aligned}
$$

and

$$
\begin{aligned}
& Q_{t}=\text { the neutron enission rate at tine } t \\
& \theta_{0}=\text { the neutron entssion rate in the absence of } \\
& \text { any } A^{241} \\
& t=\text { the tine from the start of the } \mathrm{Am}^{241} \text { accumulation } \\
& a=\text { the relative abundanee of the lsotope } \\
& T=\text { the half-11fe of the isotope }
\end{aligned}
$$

The experimentally-obtalned value of 1.27 is due to the difference in eross-sections for the higher-energy alpha particles given off by $\mathrm{Am}^{241}$. From the data supplied with the neutron source, the value of $k$ was calculated to be 0.393 . Therefore

$$
\begin{aligned}
\theta_{t} & =1.02 \times 10^{7} / \sec \{1+.393[1-\exp (-13 y / 18.6 y)] \\
& =1.22 \times 10^{7} \mathrm{n} / \sec .
\end{aligned}
$$

This It an 1ncrease of $19.7 \%$ in nevtron output over the 1962 velue.

\section{Boron Prifluoride Proportional}

Countars

Galibration of absolute strengths of neutron sources becones

a difficult problen with scintillator counters becalse their detection efficiency is depentent on the energy of the inconing neutrons. Thus to measure the absolute nux of neutrons from the devlce with a sclnillator counter, a callbrated source with a sinjlar spectrum would be needed. 
Another nethod used to neasure strengths is to slow all the neutrons down to the tame energy before they are counted. Th1s technique bas been shown to be accurate for comparing sources wth different spectra. 9 Usually some hydrogenous arterial is used to moderate the neutrons and then a thermal neutron detector is used to nessure the themal neutron flux. The uniformity in counting is a result of the noderator used. This does not necessitate that the detector's efficiency be independent of energy.

To obtain an absolute measurenent of the neutron flux from the device, a neutron detector buflt by Eberline (Kodel FHC-1. Serial \# 241) was used. It wes a $\mathrm{Br}_{3}$ proportional counter surrounded. by paraffin that is enclosed in a cadnion shleld. The cylindxicel counter tube is filled with $\mathrm{BF}_{3}$ gas.

The eross Bection of Boron is proportionel to $1 / \mathrm{v}$ in the thermel range $\left(\mathrm{B}^{10}+n+\mathrm{He}^{4}+\mathrm{Lt}^{7}+2.8 \mathrm{MeV}\right)$. The energetic products of the reaction lonite other particles in the gas. The electric fleld present then accelerates the charged part1cles, resulting in a snall avalanche, and the current in the detector indicates that a neotron has been ceptured.

Callbration of the $\mathrm{Br}_{3}$ Detector

The confinement device was located in a roov about 12 feet by 20 feet with a 7-foot celling. All the walls, floor, and celling were mate of concrete. The reflection of fast neutrons by the concrete walls around the device added to the total number of neutrons beins counted. The fast neutron albedo (fraction of reflected neutrons to Incident neutrons) for conerete ${ }^{10}$ is of the order of 0.1 . Calibrtion 
measurenents on the detector vere nade in three different locations (Fig. 12) to evaluate: the scattering effect on the counting rate. The value of $\mathrm{C}$ in the figure $1 \mathrm{~s}$ given by:

c

$$
-\frac{\mathrm{NPS}}{\mathrm{D}^{2} \times \mathrm{CPP}_{\mathrm{BF}-3}}
$$

where

$$
\begin{aligned}
& \text { NPS - Strength of source in neitrons per second } \\
& \text { D } \quad \text { Distance in cn between the center of the } \\
& \text { source to the center of the detector } \\
& \text { CPL }
\end{aligned}
$$

If a purely inverse square relationship held, then $\mathrm{C}$ woild be a constant. However, there are several reasons for the variaion of $C$ with distance. The effect of the seattering of neutions by the walls is nost noticeable at large distances fron the source bechuse of an increase in the ratlo of reflected to afrect neutrons baing counted. At small distances the effects of the shape and size of the detector result in a deviation from a $1 / 0^{2}$ relationship.

The data for the botton curve of Pig. 12 was obtalned in a room ( $8 \times 10 \times 8$ feet) singller than that in which the confinement device was located. Five of the sides were of concrete and the remalning wall was constructed of einder blocks (8 $\times 10$ feet with a $3 \times 7$ foot door). The data for the aiddle curve was taken in a roon larger than the experinental area, and the top curve near the edge of a belcony in a very large open room. The botton and niddis curves should bracket the conditions of the roon in whlch the experinent was performed as far as the evaluation of 6 is concerned. In the 


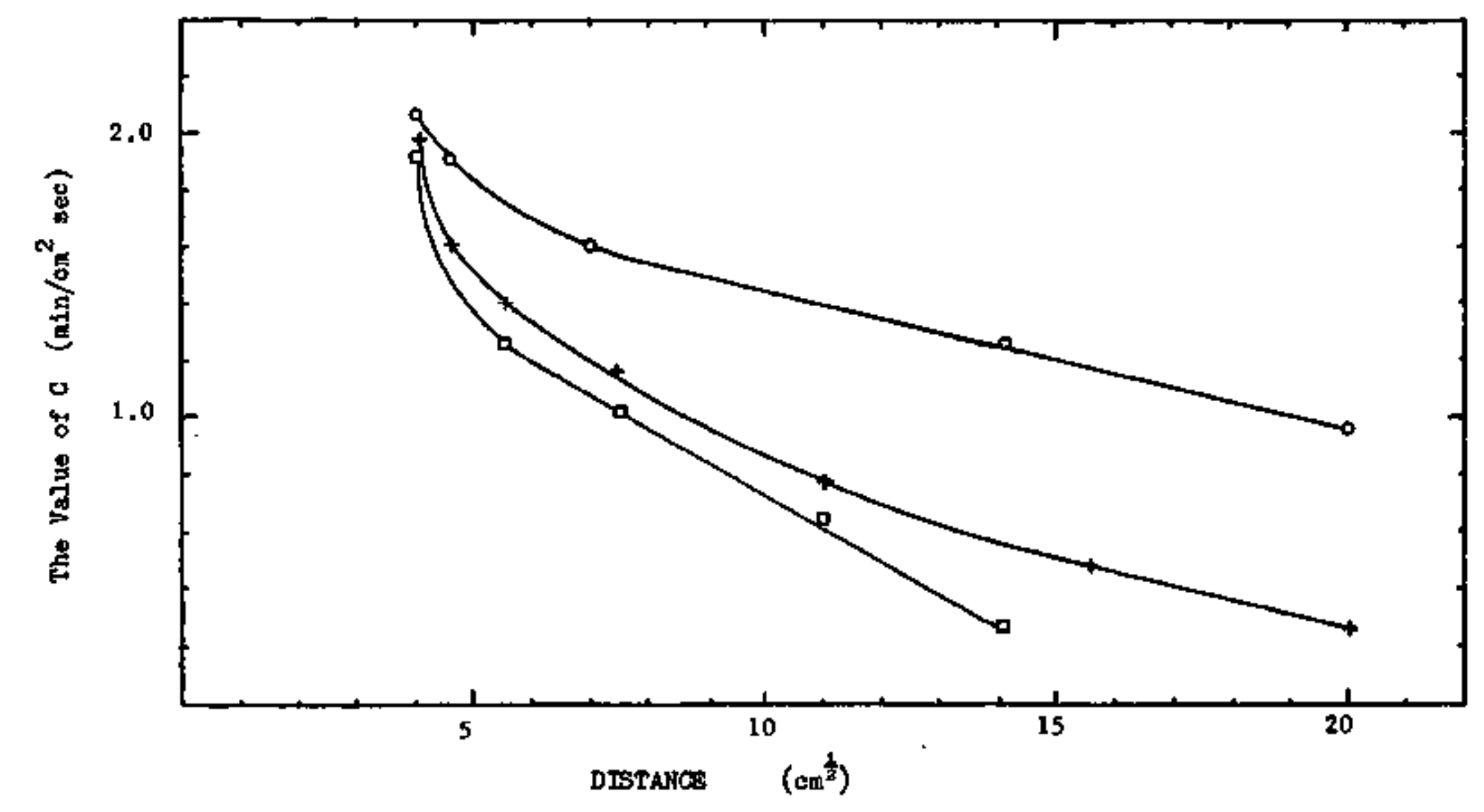

Flgure 12. The Value of $\mathrm{c}$ as a Function of Distence 
experiment the center of the detector was located 32 ca from the center of the confinement derice. The value of $c$ to be used in the experinent should thus be between 1,25 and 1.40 . A value for 0 of 1.3 is chosen as the best estimate for the sensitivity of the datector under the laboratory condittons present. This val ue is oonsidered to be accurate to within about $10 \%$. Thus

$$
\mathrm{NPS}=(1330 \pm 133) \times \mathrm{CPH}_{\mathrm{BF}-3^{*}}
$$

\section{Calibration of Scintillation}

Detectors

To caltbrate the sointillation detectors runa were exanined in which the counting rates for both the $\mathrm{BF}_{3}$ and seint1llation detectors hat been recorded (F4g. 13). The correlation coefflelent between the counting rates for the two types of detectors was 0.9 fl wh nost of the error due to inaccuracy in reading the $\mathrm{BF}_{3}$ detector and statistical fuctuations in the counting rates. The result was

$$
\mathrm{CPS}_{\mathrm{SCEn}}=5.8 \times \mathrm{CPH}_{\mathrm{BF}-3}
$$

or

$$
\text { NeS }=230 \times \text { MPS }_{\text {Scin }}
$$

where

$$
\begin{aligned}
\text { GPS }_{\mathrm{Scin}}= & \text { counts per second in the scintillation } \\
& \text { detectors }
\end{aligned}
$$

Data shown In Fig. 14 represent sone of the Information on counting rates obtained from the confinement device, ht $50 \mathrm{keV}$ and a pressure of $1.25 \times 10^{-3}$ Torr, the count1ng rate was 120 eps per mill1ampere. Assuming a linear dependence on current, this corresponds to about $2.7 \times 10^{5}$ neutrons per second at 10 mill1amps. H1rsch ${ }^{1}$ for 50 keV, 10 milizamps, and $1.1 \times 10^{-3}$ Torr reported a rate of $1.5 \times 10^{6}$ 


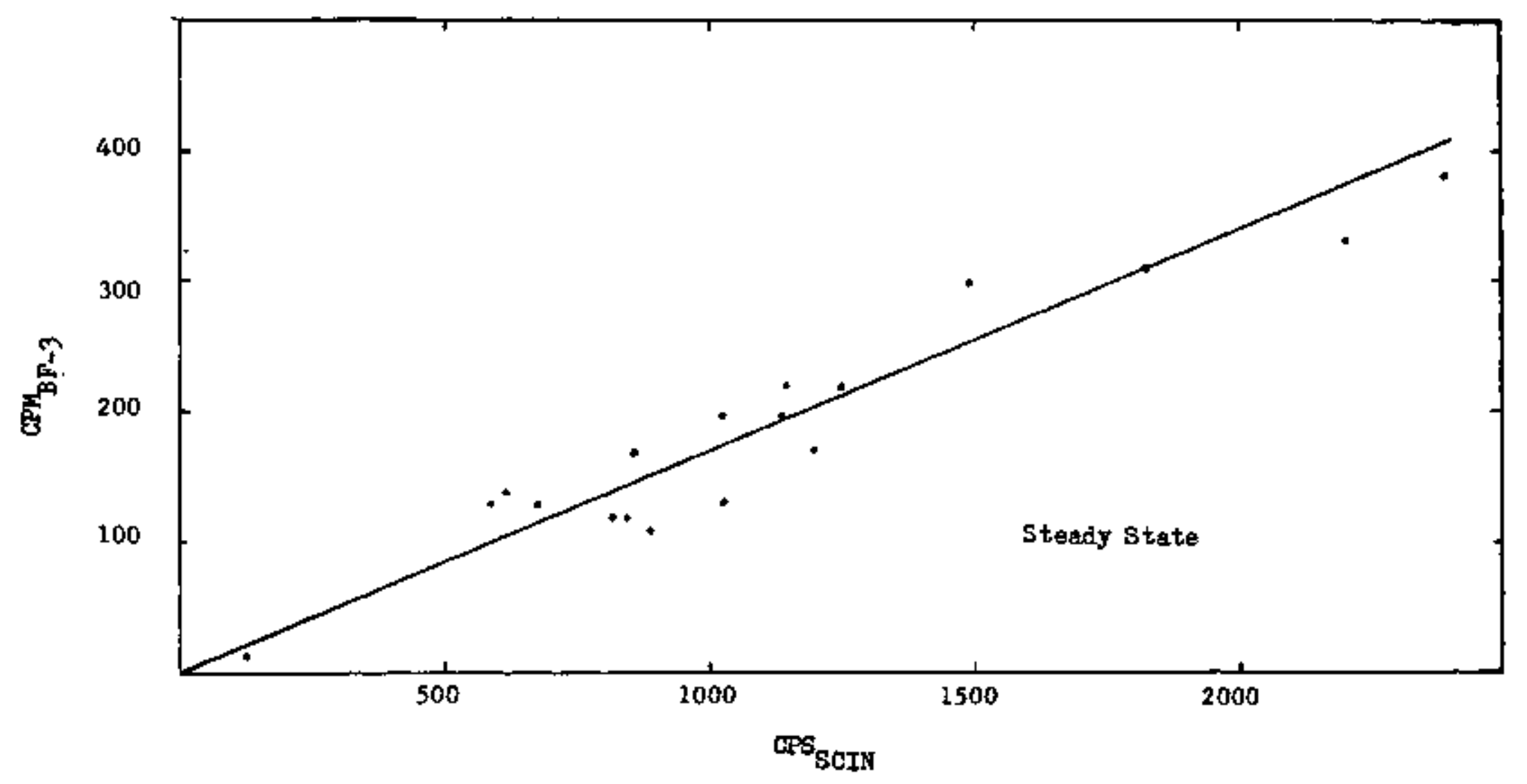

Figure 13. Comparison of Counting Rates for the $\mathrm{BF}_{3}$ and the Scintillation Detector 


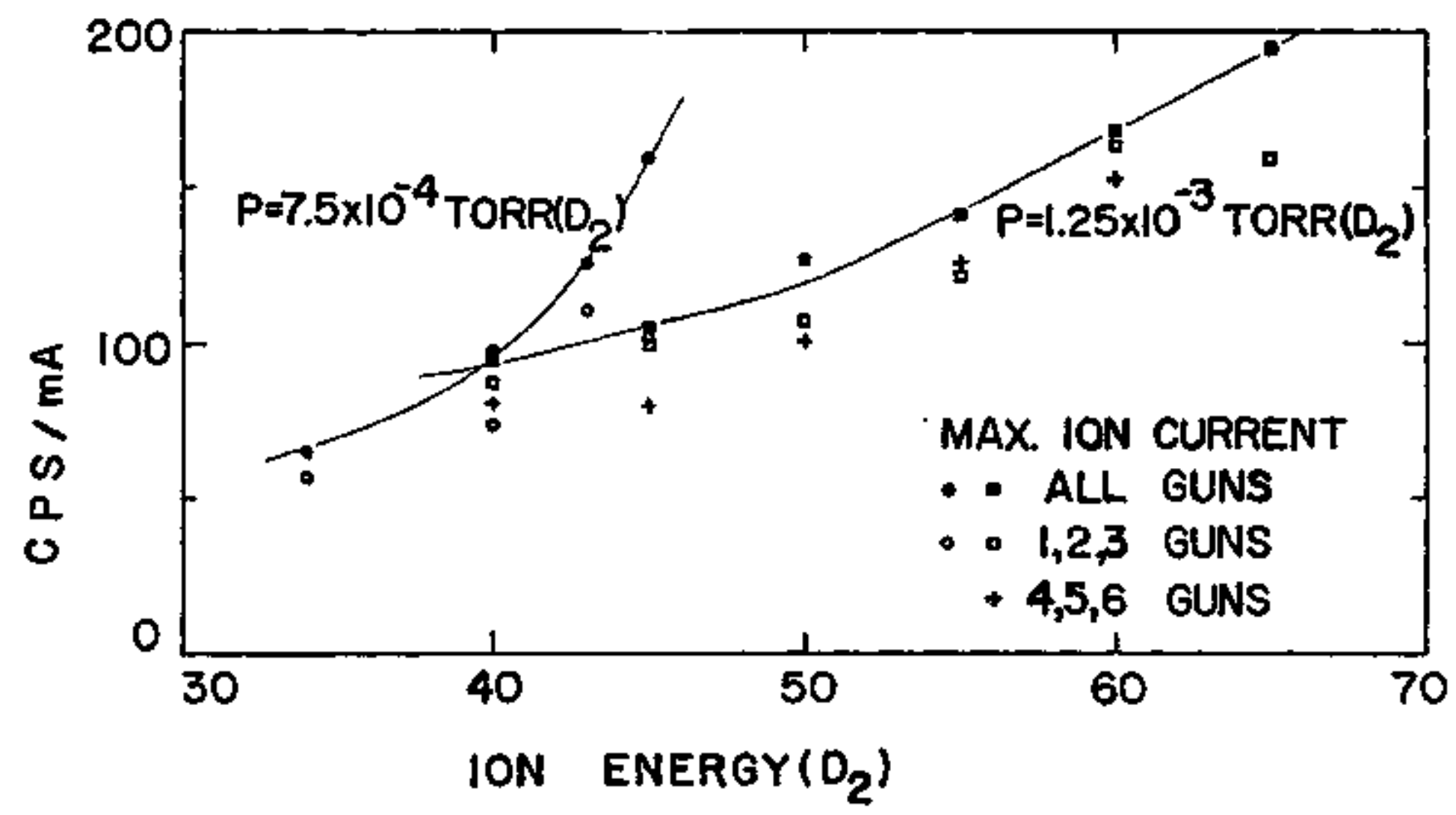

Figure 14. Measurenents of Neutron Flux from the Confinenent Device 
neutrons per second. Minor changes in the device and such factors as the alignnent and focusing at the ion beans could easily account for the difference.

Efficleney of the Scintillation Detector

The efflelency of the selntillation detectors is deterinined Fron the fraction of the number of neutrons recorded to the nunber of neutrons passing through the detectors. The distance from the center of the scintillation naterial to the center of the confinenent dovice was ten Inches. Comparing the cross-sectional area of the detectors $\left(\pi \times 2.5^{2} \mathrm{in}^{2}\right)$ to the area of a sphere with a radiug of ten inches. gives a ratio of 1 to 32 . This means that for every 32 neutrons leaving the device, one, on the average, w1ll pass through the detector. However, one count has been detertalned (see above) to correapond to an enfseion of 230 neutrons fron the confinenent device, but part of the counts are a result of reflected neutxons. Th1s 1mplies that the efflclency of the detector is below $14 \%$. Most of the reflected neutrons have lost energy in scattering collisions and probably add IIttle to the counting rate because of rejection of low anplitude pulses by the alserininator. Snall changes in the discrininator or anpliflier settings influenced the counting rate. Higher efficlencles sould have been obtalned by accepting pulses with a lower anpl1tude, but this would have resulted in an increase in unwanted background counts. 
Energy Calibration

By exalning the helght of the light pulses in the detector, one can determine the energy spectirum of the protons in the $n-p$ scatterings. This is related to the energy of the neutrons. A Fu-Be source was uged to calibrate the detectors. The energy spectra for Pu-Be sources have been determined by many different methods and the general shape $13 \mathrm{known}$. F1g. 15 show the neutron energy spectrom 11 for several known sources. Fig. 16 shows the energy spectrum of the protons scattered by the neutrons fron the Pu-Be source. The derivative of $\mathrm{Mig} .16 \mathrm{is}$ given in Pig. 17. Ideally this would correspond to the neutron energy spectrune fron the Pu-Be source. Hatching the maxima and mining points indicated by letters in Fis. 17 with points indicated by corresponding letters in Flg. 15, the energy velues shown in 81g. 17 were assigned. The correlation coefficient between the energy values of the points in F4g. 15 and the channel number of the corresponding points of Fig. 17 was nearly one. Thus knoring the response of the detector, the energy values of the spectrum (Fig. 18) fron the confinement device were determined. Flg. 18 shows that nost neutrons fron the device had an energy of about $2.5 \mathrm{HeV}$. The ' principle reactions taking place in the device are: $\mathrm{D}+\mathrm{D}+\mathrm{He}^{3}+\mathrm{n}+$ $3.2 \mathrm{MeV}$, and $\mathrm{D}+\mathrm{D}+\mathrm{T}+\mathrm{p}+4.0 \mathrm{MeV}$. Farticles other thar neutrons are stopped fron reaching the detector by the walls of the confinenent device. Applying the principle of conservation of momentum to a celculation of neutron energy shows that nost of the neutrons will carry away about $2.4 \mathrm{MeV}$ of energy, which is approximately the value noasured. 


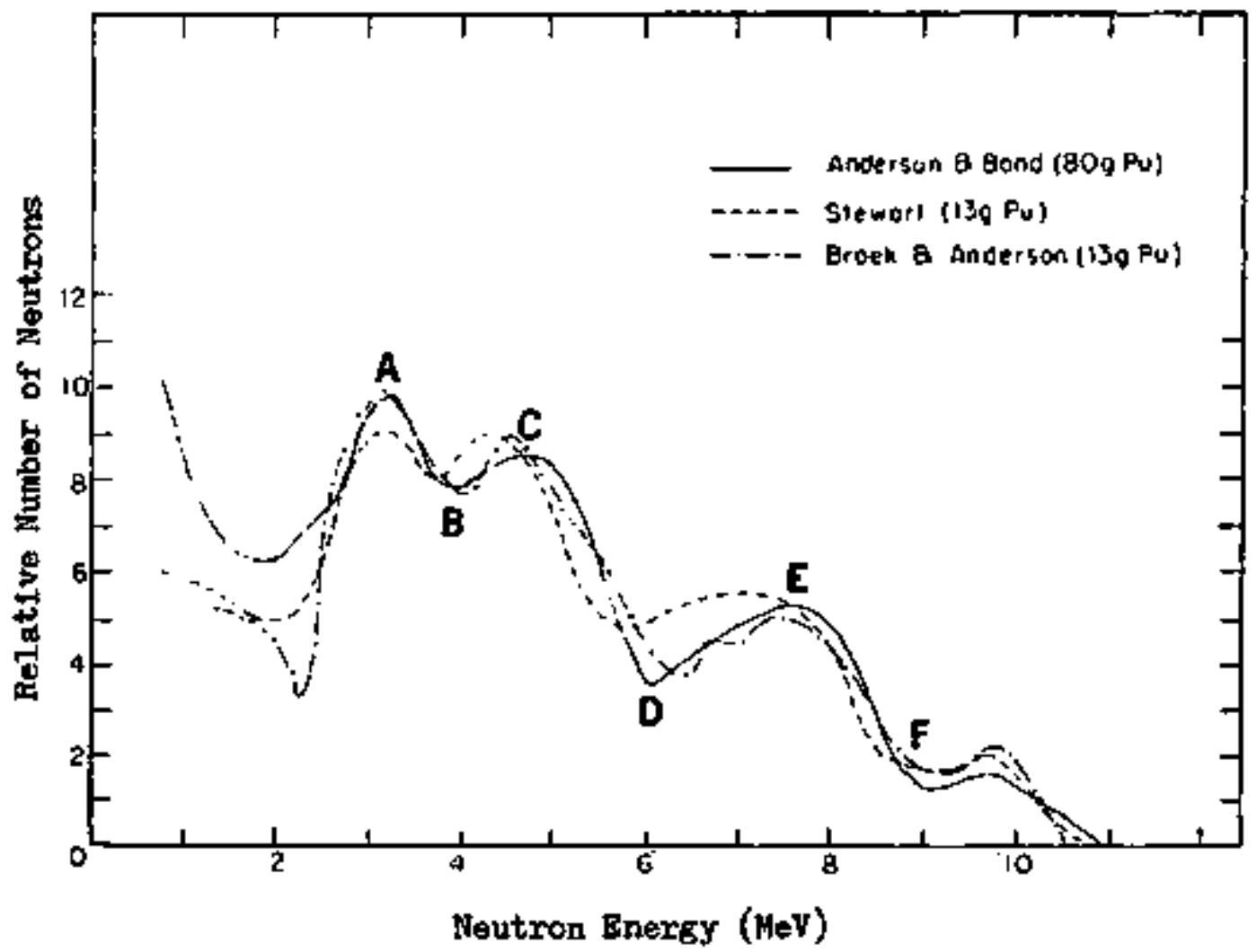

Flgure 15. Known Energy Spectra of Pu-Be Sources 


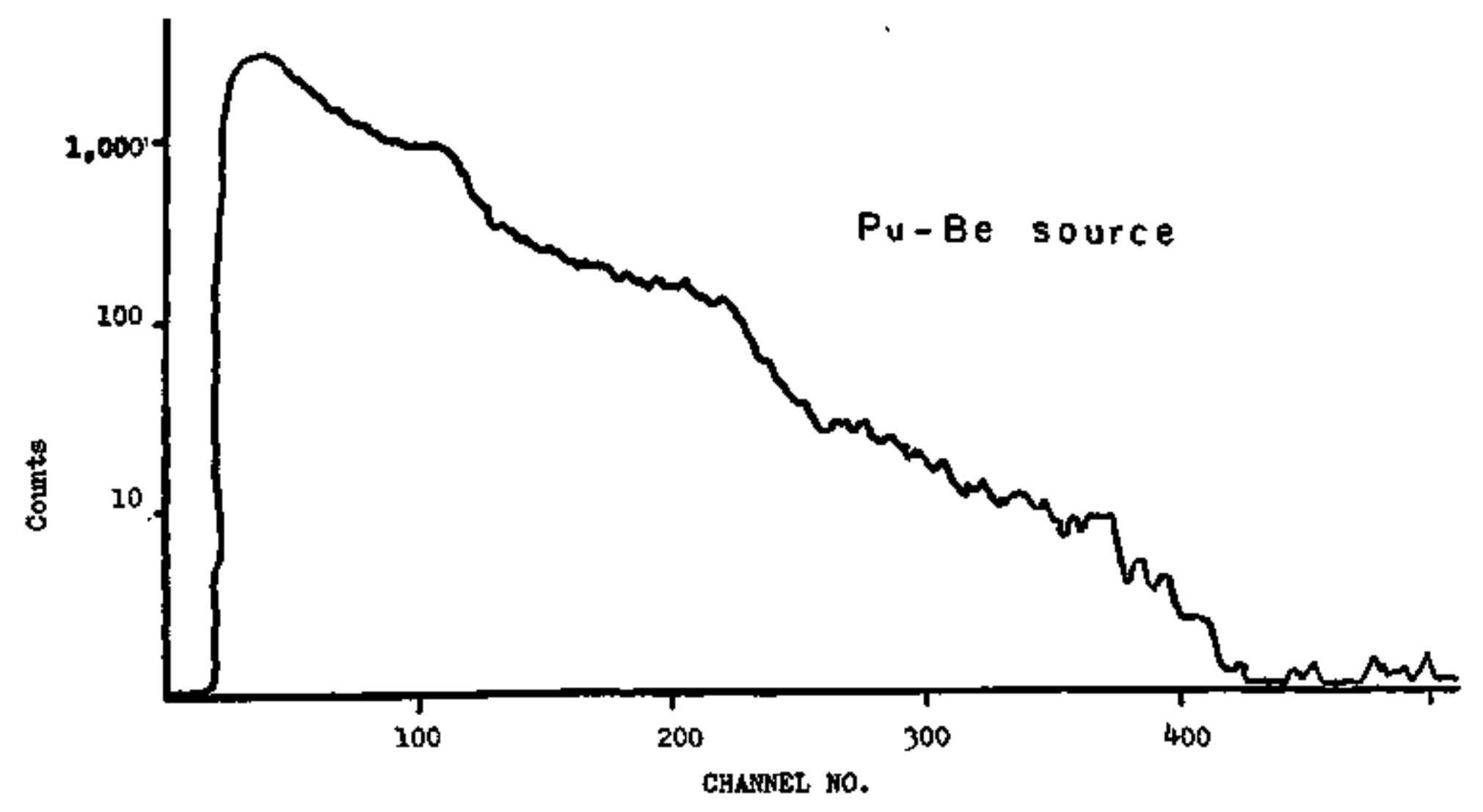

Mgure 16. Energy Spectrum of the Protons Scattered by the Heutrons fron the Pu-Be source used 


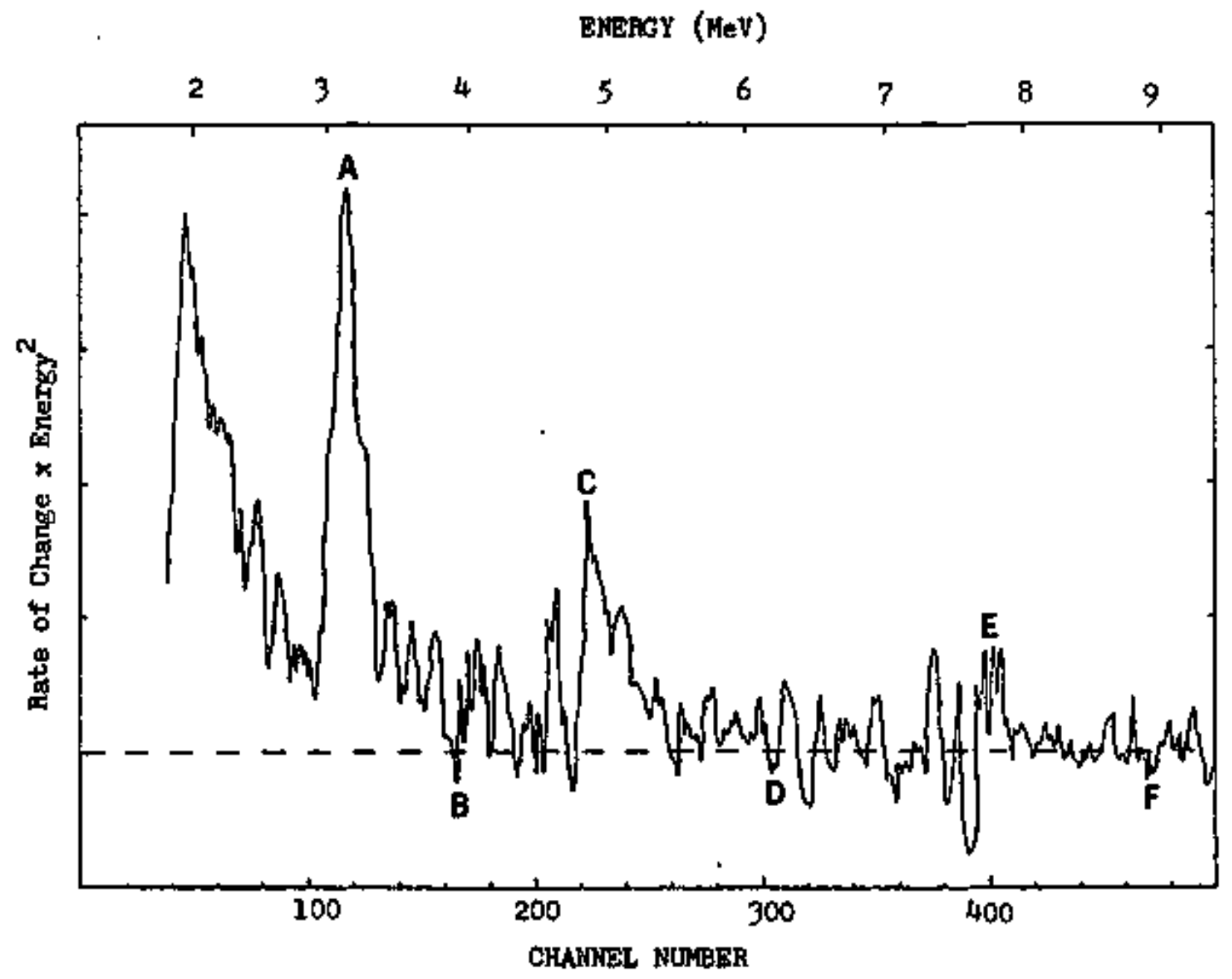

Plgure 17. Derlvative of the Energy Spectrun Shown In Fig. 16 


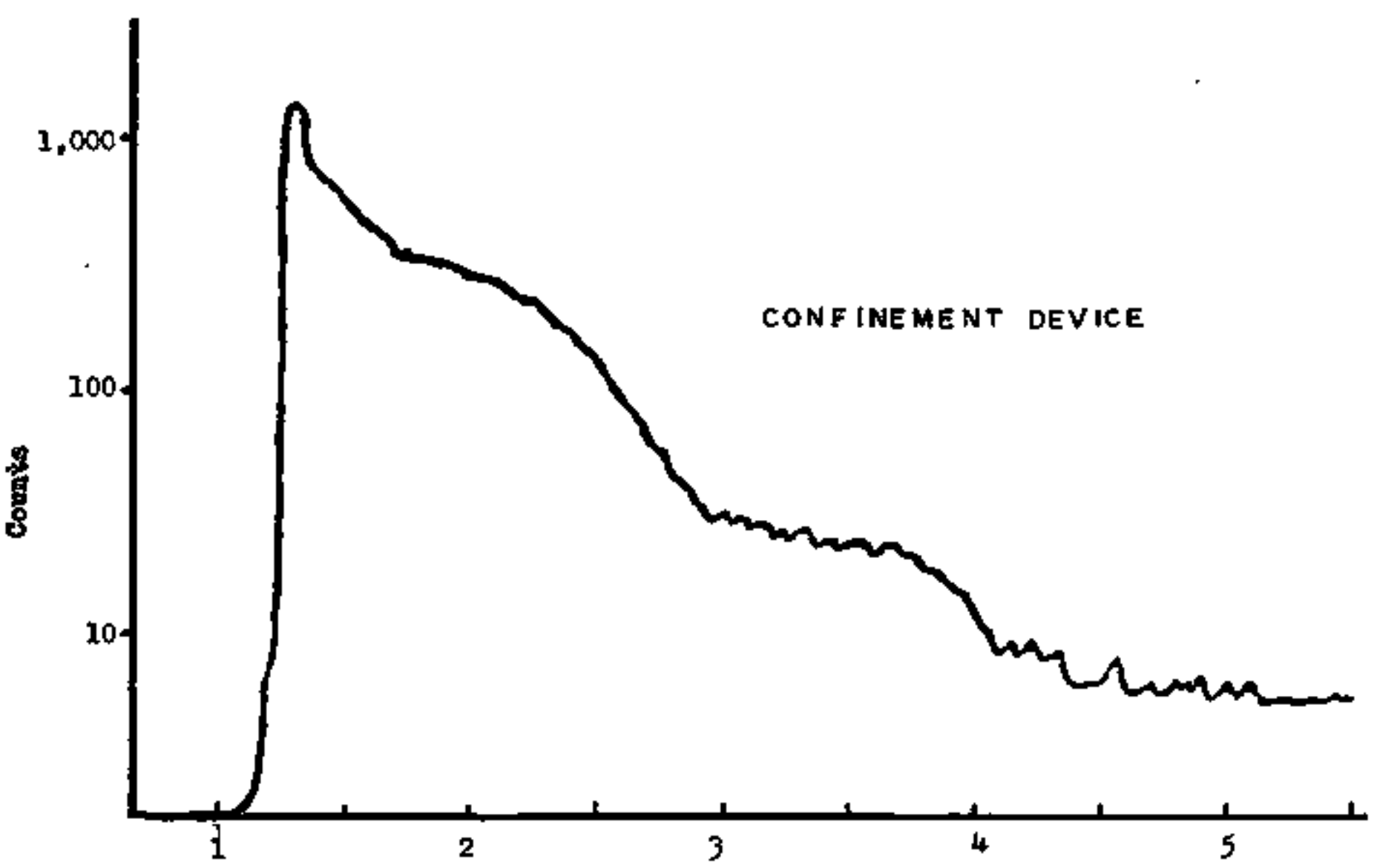

Fisure 18. Energy Spectrum of the Protons Scattered by the Neutrons from

Conflnement Device 
Chapter 5

SHTTCHDD OFBRATION

Hany of the counting rate neasurements were taken simultaneously with measurenents of electron density. The latter neasurenent required that the high voltage be continuously switched in order to provide a comparison between "on" and "off" condittons and to avold thermal expangtion of the cathode, which was used as a resonant cavity. Triggezlng and gate pulses bad been prepared ${ }^{32}$ for electron density neasurenents, Fig. 19 shows the pulses used for neutron counting and the cathode voltage diming one suitching cycle. Fig. 20 shows the counting rates over the same tine period for hyirogen and for deutorlun. Counting rates were neasured for times around 100 isec on the figure and the background rates yere neasured for times around 200 nsec. The ripple in the counting rate is a result of the 120 cycle ripple in the high-voltage supply. A surge in the counting rate, for t1mes between 20 to 60 alsec was observad for both the hydrogen and deuteritum. This suggests nany of the counts recorded during the surge for deuterium were not a result of fusion reactions but were from other sources.

The $\mathrm{BF}_{3}$ detector averaged the counts over the entire cycle. Fis. 21 shows readings for the same voltage made simultaneously on both the $\mathrm{BF}_{3}$ and the selntillation detector. Values for the counting rate for the scintillation detector were teken for times aroumd 100 msec. Undex these conditions, the counting rate for two detectors 10 


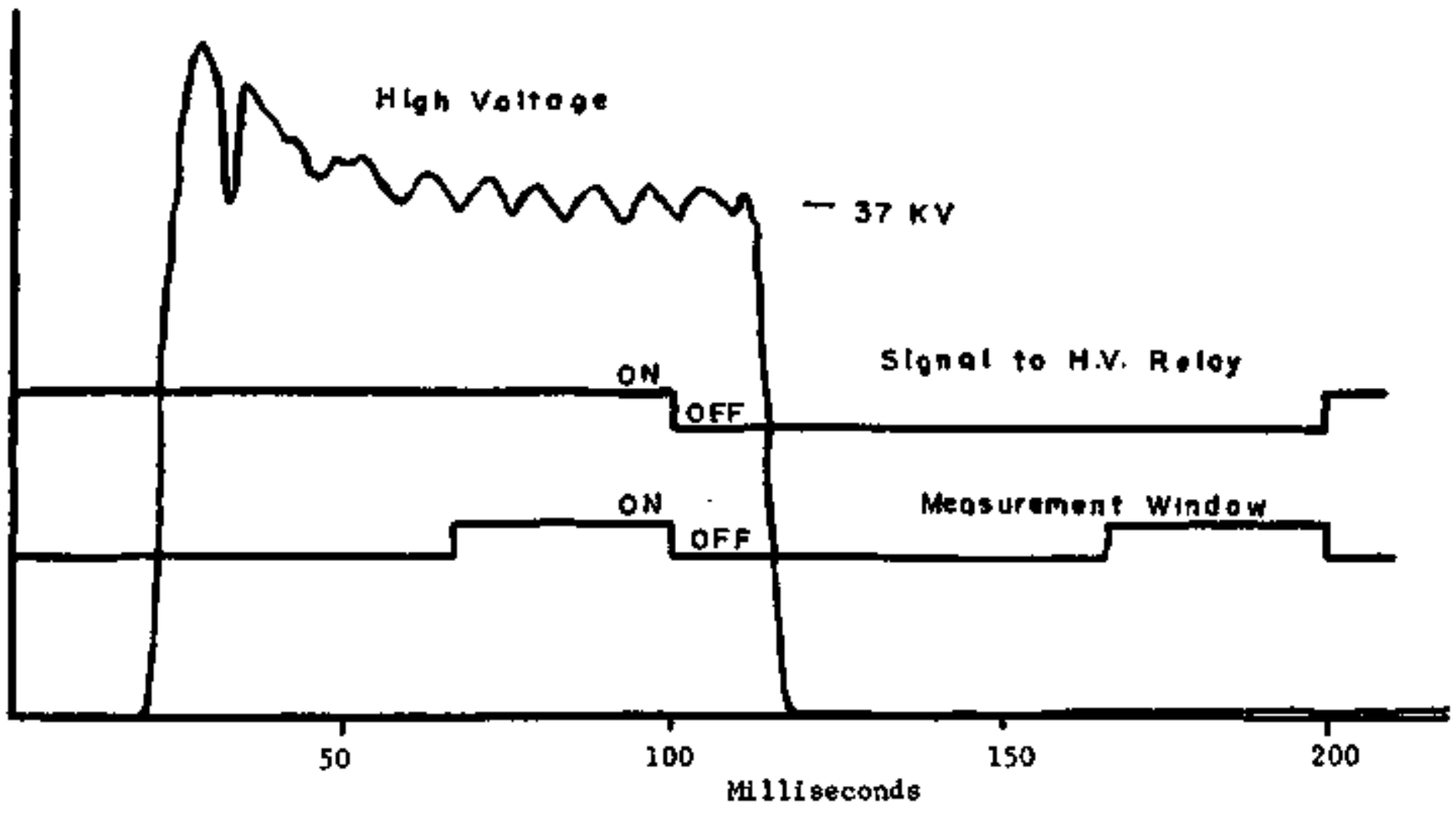

Figure 19. Cathode Voltage and cating Pulse During attching Cycle 


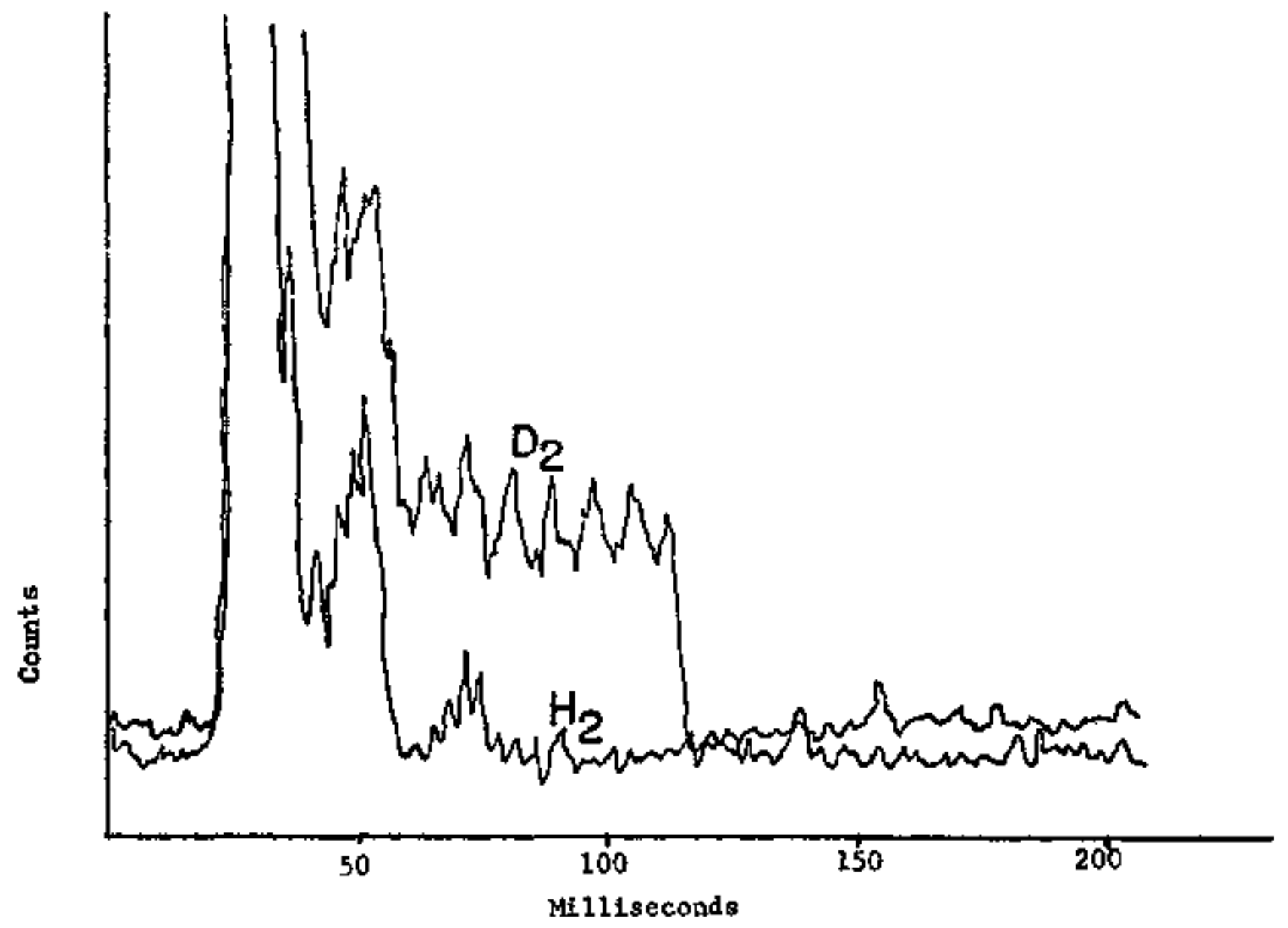

P1gure 20. Counting Rates During a Swtcching Cycle for $\mathrm{D}_{2}$ and for $\mathrm{H}_{2}$ 


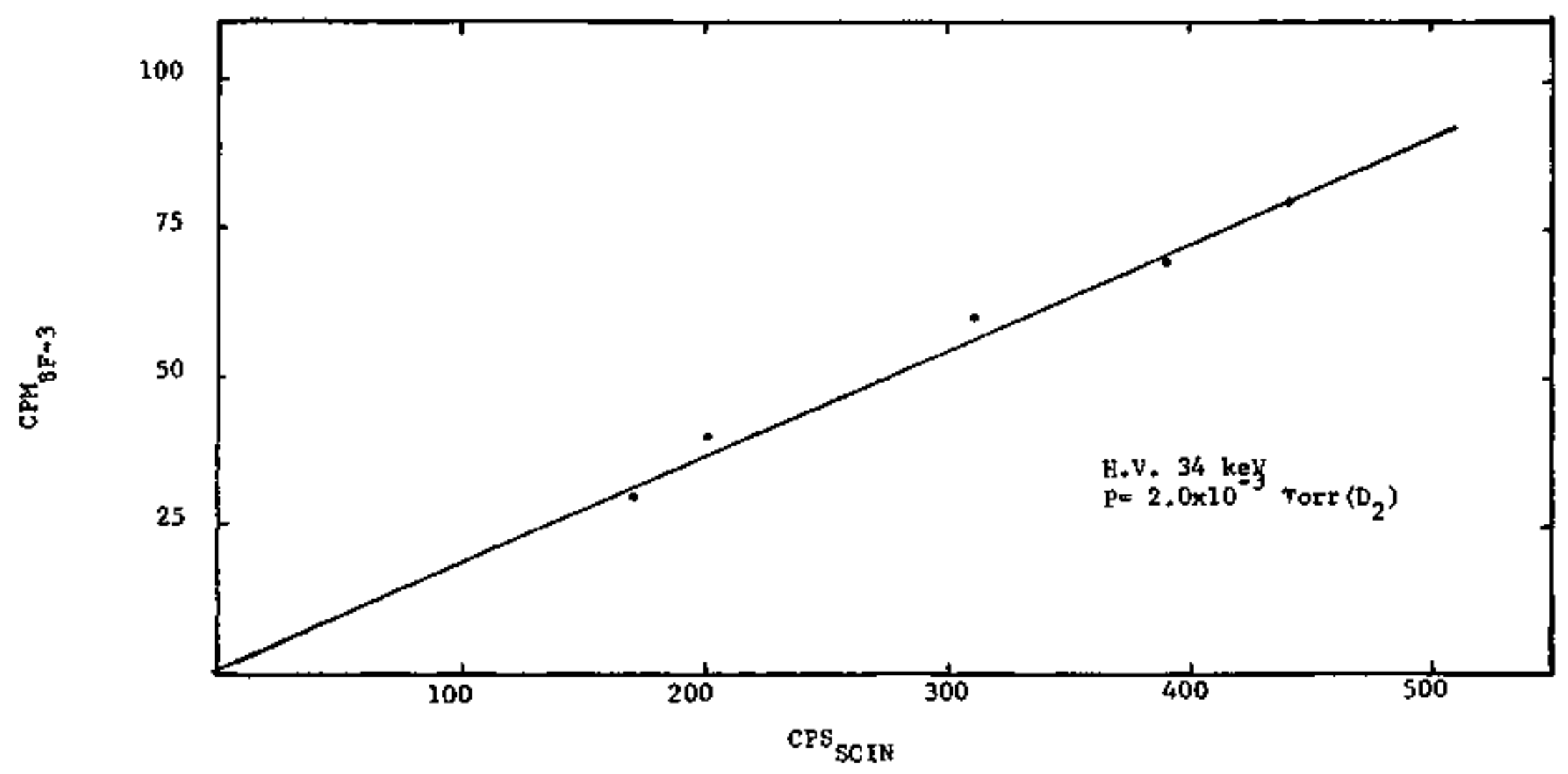

Figure 21. Comparison of Counting Rates of $3 F_{3}$ and the Scintillation Detectors for the Switched Condition 
related by

$$
\mathrm{CPS}_{\mathrm{Se1n}}=5.6 \times \mathrm{CPH}_{\mathrm{BP}-3}
$$

When hydrogen was used in the device, the counting rate of the $\mathrm{BF}_{3}$ detector was zoro. The small difference in the constant that relates these two detectors for the ateady state (5.8) and the switched state (5.6) indicates that with suitched operation there $1 \mathrm{~s}$ a high rate of neutron enfigston at the first part of the cycle, wheh essentially compensates for the tine the high voltage is twened off. Higher voltages and currents are to be expected in the surge conditions at the beginating of the "on" time.

One of the objectives of butlding a nore sensttive neutron detection system was to neasure siall changes in neutron output due to changes in the symmetry of the active lon guma then lese than six guns were used. To do thls, neutron output per millianp was conpared. for sets of suns that were symetrlcally opposed to each other (all guns) and for nor-opposing sets (guns 1, 2, 3 or 4, 5, 6). Above 40 keV (when the mlcrowave detection could not be used) the neutron detectors indicated a siall enhancenent, when all the zon guns were operated simultaneously, over that obtalned with operation of nonopposing sets of guns. 


\section{Chapter 6}

\section{SINRTARY}

Thts thes1s has discussed a neutron-detection systen that was used to measure the neutron flux fron an Inertial-pilectrostatic Confinoment Device. These measurements have been used to analyze the operation of the confinenent devlce located at Brighan Young University. The neutron counting system was made to be able to detect small changes in operating conditions, and to be able to make reasurements under conditions where the high voltage of the device was sultched "on" and "off".

Two identical selatillation counters were constructed that would be able to nake relative flux measurements for conparison of different operating condftions. These detectors were checked for their sensitivity to ganna rays from the confinenent device.

$A \mathrm{BF}_{3}$ propoxtional countex was calibrated using a Pu-Be source with corrections hade for laboratory conditions. This detector was then used to callorate the scintillation detectors to nake quantitative flux masurenents.

The detectors were used to make neasurenents for several hundred different combinations of voltage, eurrent, and pressure with all Ion gums operating, and s1milar measurenents for cases where only part of the Ion gins were in use. These nessurenents provided inforsation of interest about the device. 
APFEFID $D$ 
SFECIPICATIOAS OF PHOTOMULTIPLIER TUBES

\begin{tabular}{|c|c|c|c|c|}
\hline Tube & $x-32794$ & $T-33424$ & $x-36150$ & $x-36246$ \\
\hline $\begin{array}{l}\text { White Cath. Sens. } \\
\mu a / \text { unen }\end{array}$ & 190 & 290 & 140 & 200 \\
\hline $\begin{array}{l}\text { Anode, Sens, at } \\
25000 \text { amp/lumen }\end{array}$ & 6400 & 2000 & 12000 & 15000 \\
\hline Dark Current in & 0.7 & 11 & 0.46 & 0.45 \\
\hline Volts & 2040 & 2400 & 1930 & 1815 \\
\hline $\begin{array}{l}\text { Dark Current } \\
\text { at } 25000 \text { ua }\end{array}$ & 6.4 & 19 & 20 & 28 \\
\hline $\begin{array}{l}\text { Red Sens, with } \\
\text { Cornins fllter } \\
\text { c s2-62 } \\
\text { ua/1ncident limen }\end{array}$ & 82 & 110 & 42 & 82 \\
\hline $\begin{array}{l}\text { Blue sens, vith } \\
\text { conn1ng fllter } \\
\text { c s-558 } \\
\mu a / \text { incident lumen }\end{array}$ & 6.2 & 1.7 & 8.3 & 7.0 \\
\hline
\end{tabular}




\begin{tabular}{ll}
\hline 1. No connection & 11, Dynode 14 \\
2. Dynode 1 & 12. Dynode 12 \\
3. Dynode 3 & 13. Dynode 10 \\
4. Dynode 5 & 14. Dynode 8 \\
5. Dynode 7 & 15. Dynode 6 \\
6. Dynode 9 & 16. Dynode 4 \\
7. Dynode 11 & 17. Dynode 2 \\
8. Dynode 13 & 18, No connection \\
9. No connect1on & 19. Focus grid \\
10. Dnode & 20, Cathode \\
\hline
\end{tabular}

Tubes are red sensitive and peak around $400 \mathrm{~nm}$. The outitide shleld should be at cathode potential. Operate with as low of voltage as possible. About $1800-2000 v$. The output 1mpedence is fifty to several thousand ohns. The tubes have tine constants around $10 \mathrm{~W}$ sec. The focusins grid is Internally connected to the netwl flange. 
REFHENCES 
$1_{\text {Robert }} \mathrm{L}$, Hirsch, "Inertial-Electrostatic Confinement of Ionized Fusion Gases," Jourial of Applied Physics, Vol, 38, Ho, 11, p. 4522 (7967).

2 Austen Inn-Young Chan, Microwave Measurements of Election Density in a Spherical Inertial-3lectrostatic Confinenent Syotem Using Six Ion Guns," (19/5) Ph,D, Dissertation, Departnent of Physics and Astronony, Brigham Young University, (Repoxt No, C00-2180-5 prepared for the U.S. A.E.C. under contract No, AT(11-1) -2180).

3W. E. Burchan, Huclear Physlos. (MoGran-Hill Book Go. Inc., Hew York, 1963), p, 280 .

4R. B. Murray, "Seintillation Counters," fuclear Instrupents and Thelr Uses, ed. Arthur H. Snell. (John Wiley \&ons, Inc., New York, 1962), Vol. 1, p. 160.

Suclear Enterprises, Inc, San Garlos, Gallfornia, Plastic Scintillators: Light Pipos and Cerenkov Detectors, p. 3 .

6 United States Atonic Enexgy Connission, Reactor Handbook: Physics. (McGraw-Hill Book Co. Inc., New York, 1955), p. 642.

? Information on Pu-Be Source obtatned frop the Monsanto hesearch Corp., April 6, 1962.

B. E. Tate and A, S. Coffinberry, Plutoniun-Beryllius Neutron Sources, The1r Fabrlcation and Neutron Yield," Proceedings of the Second United Nations International Conference on the Peaceful Uses of Atonte Bnexsy, Vol $14 ;$ Fuclear Physics and Instruanentation, (Inited Hations, Genevs, 1958).

Burchat, p. 283-287.

10 ${ }_{\mathrm{R}}, \mathrm{P}$. Evans, "Instrunentation for $\mathrm{C}$ ont1nuously Recording Plasma-Induced Frequency Shifts of Tro Microwave Cav1ty Resonances," 1974, M.S. Thesis, Departnent of Physics and Astronony, Brigham Young Inivertity. (Report No. COO-2180-3 prepared for the U.S. A.E.C. under contract No. $M T(11-1)-2180)$.

11., B. Anderson and W. H, Bond, Jr.., "Neutron Spectrun of a Pluton1un-Beryll1un Source," Nuclear Physics, 43, 330 (1963) 
12 R. P. Evans, "Instrumentation for Continuously Foconding Plasma-Induced Frequenoy Shifts of Two Microwave Cavity Resonances," 1974, M.S. Thesis, Depertment of Physics and Astronomy, Brighan Young University. (Ateport No, G00-2180-3 prepared for the U,S, A,E,C. under contract No. AT(11-1) = 2180). 